\title{
A Comprehensive Analysis of Maternal and Newborn Disease and Related Control for COVID-19
}

\author{
Nevio Cimolai ${ }^{1,2}$ (1) \\ Accepted: 22 February 2021 / Published online: 17 March 2021 \\ (C) The Author(s), under exclusive licence to Springer Nature Switzerland AG 2021
}

\begin{abstract}
The maternal-fetal/newborn unit is established at risk for COVID-19 infection. This narrative review summarizes the contemporary and cumulative publications which detail maternal infection, antenatal and newborn infections, and maternal/fetal/newborn management and prevention. There is a wide spectrum of maternal disease, but the potential for severe disease albeit in a minority is confirmed. COVID-19 carries risk for preterm delivery. Pregnant females can suffer multisystem disease, and co-morbidities play a significant role in risk. Congenital infection has been supported by several anecdotal reports, but strong confirmatory data are few. No typical congenital dysmorphisms are evident. Nevertheless, placental vascular compromise must be considered a risk for the fetus during advanced maternal infections. Clinical manifestations of newborn infection have been mild to moderate and relatively uncommon. Proven antiviral therapy is of yet lacking. The mode of delivery is a medical decision that must include patient risk assessment and patient directives. Both presymptomatic and asymptomatic mothers and offspring can complicate infection control management with the potential for spread to others in several regards. In the interim, infections of the maternal-fetal-newborn unit must be taken seriously both for the disease so caused and the potential for further dissemination of disease.
\end{abstract}

Keywords COVID-19, $\cdot$ Coronavirus, $\cdot$ Maternal, $\cdot$ Fetus, $\cdot$ Newborn, $\cdot$ Pregnancy

\section{Introduction}

The maternal-fetal/newborn unit has not been spared from pandemic COVID-19 infection [1,2]. What was debatable very early on was the possibility that maternal-fetal transmission could occur and the magnitude of disease among both mother and infant [3]. Considerable experience has emerged and has provided sufficient data that may be used to better understand the epidemiology, disease course, and prevention for maternal-newborn care.

There are four key considerations that set the foundation for this review. These are based on the understanding of both the basic science and the clinical parameters of SARS-CoV-2 infections. The first of these is that maternal infection does

This article is part of the Topical Collection on Covid-19

Nevio Cimolai

ncimolai@mail.ubc.ca

1 Faculty of Medicine, The University of British Columbia, Vancouver, Canada

2 Children's and Women's Health Centre of British Columbia, 4480 Oak Street, Vancouver, B.C. V6H3V4, Canada occur as would be anticipated, but the clinical presentation is considerably variable. Secondly, newborns do acquire infection early and late postnatally, and the fetus can be impacted by maternal illness regardless of whether antenatal infection does or does not occur. Third, prevention and control management strategies for the pregnant female are therefore required. Lastly, prevention and control management strategies are also needed for the fetus and newborn. It is these four broad topics of review which set the stage for other aspects of supportive treatment, prevention, and necessary follow-up.

This narrative review was accumulated after thorough review of related publications as abstracted in PubMed, EMBASE, CINAHL Plus, and the Cochrane Library. The compendium of material was current to the end of December, 2020.

\section{Maternal Infection with SARS-CoV-2}

\section{Nature of Disease}

Clinical characteristics and associated morbidity and mortality from SARS-CoV-2 infections generally have been aptly 
characterized in many reports to this point $[4,5]$. The presenting illness is mainly one of the upper and/or lower respiratory tracts. Patients may less commonly progress to an advanced pulmonary crisis which requires intensive care and oxygenation. Most systemic facets of disease are largely ascribed to severe complications arising from a cascade of pathological and immunological events in the lung [6]. Age and comorbidities factor as risks for accentuated illnesses. Demographic variables otherwise may also predict risk for infections in pregnancy specifically [7].

COVID-19 infection does not seem to be acquired among pregnant patients any more than the general population [8]. Infection however does not spare any trimester of gestation [9-14]. Some reports suggested that COVID-19 in pregnancy is analogous to the disease experienced in the general population [1, 4, 15-17]. From Denmark, a cohort study did not find ultrasound evidence of fetal compromise during first trimester infections nor increased pregnancy loss [18]. The latter was supported by comparative studies in which infected pregnant patients were compared to either non-infected pregnancies, non-pregnant infected females in the community, or patients with alternative virus infections [19-24]. In this context, the study of Wei et al. stands out in that both pregnant and nonpregnant controls equally had a high rate of influenza virus codetection [17]. Nayak et al. did not find a difference for maternal complications between infected and non-infected pregnancies [21]. The latter was also found in an Iranian population, but more COVID-19-infected pregnancies required intensive care [25]. In the study of Cheng et al., pregnancies with COVID-19 were said to have less severe disease than non-pregnant patients, but the control group was significantly older for age [19]. Evidently, the pre-selection of the patient population for testing influences the likelihood of severe disease [26]. In the latter study, all incoming pregnancies in a California setting were offered screening despite being asymptomatic, and the SARS-CoV-2 positive frequency was 0.43\% during April-May, 2020. Collin et al. thereafter provided data which suggested that infected women, either pregnant or postpartum, were more likely to have a complicated course compared to non-pregnant females of equivalent age [27]. The diversity of infection in pregnancy and the magnitude of potential complications have now become more apparent [2, 9-11, 14, 28-44]. It is of interest to see how COVID-19 disease in pregnancy parallels that which was formerly experienced in the SARS era [45]. Symptoms may last for up to 1-2 months in the extremes of resolution [9].

Concerns over disease potential for mother and fetus led some to consider pregnancy termination in the first and second trimesters when the knowledge base for COVID-19 was rudimentary $[22,23,43,46]$. Gastrointestinal illness occurs in a minority of pregnancies [3, 47]. The latter is common however in other COVID-19-infected populations [48]. Although causation may be multifactorial and complex, pre-eclampsia and eclampsia were complicated by COVID-19 infection [38, 49-59]. In contrast, Gulersen et al. found a near equal frequency of preeclampsia between infected and controls, and Adhikari et al. did not find that pre-eclampsia was associated with infection $[60,61]$. Another similar citation distinguished the putative presentation of pre-eclampsia and HELLP syndrome [62]. Coagulopathy has been highlighted as a complication of special concern in COVID-19 generally and as in pregnancy otherwise [63]. Blood dyscrasias from COVID-19 must be differentiated nonetheless from chronic illness that occurs in pregnancy for other reasons [64]. Healthcare workers are among those with infected pregnancies [65]. In one study, up to $13 \%$ of infections occurred for mothers with gestations $<13$ weeks [43]. In the US, $\sim 5-9 \%$ of women with COVID-19 were identified to be pregnant $[33,44]$. Tug et al. found more severe illness among pregnancies after 20 weeks gestational age [42].

Severe respiratory disease requiring extra-ordinary treatment or monitoring is consistently described $[2,10,13,14,19,28,30-33$, 39-41, 43, 44, 46, 47, 59, 61, 66-91]. Cardiac disease may accompany the latter [92]. The frequencies of severe illness have been variably inclusive of 3-25\% of the infected mothers, but these numbers are influenced by the variation that is inherent for admitting patients to hospitals or in the classification of disease severity at presentation or thereafter. A study from Spain found that nearly $50 \%$ of patients with pneumonia subsequently suffered what would have been classified as severe disease [86]. Regardless, however, COVID-19 can be directly implicated as a cause of maternal demise [4, 12, 21, 30, 32-34, 39-41, 44, 47, 68, 72, 76, 80, 88, 93-98]. In Brazil, most such maternal deaths were occurring in the postpartum period [96]. Others have found similar timing [3]. Rios-Silva et al. did not find a difference for maternal demise among COVID-19 infections and controls [4]. Despite the latter, asymptomatic presenting infections are common [2, 41, 43]. Cosma et al. found that disease in very early pregnancy is likely to be relatively mild [11]. Disease progression and duration of symptoms did not apparently depend on the trimester of infection [14]. Generalizing, more severe illness tends to be found among maternal populations of lower socioeconomic status, but there is nevertheless great variation.

Obstetrical complications associate with infection generally [99]. Some complications may depend on the nature of the symptomatic and asymptomatic state [56]. Preterm delivery is relatively common, but the frequency has been considerably influenced by concerns for the pregnancy and hence by iatrogenic intervention $[2,13,23,29-31,34,35,37,39-42,46,55$, 56, 59-61, 66, 68, 77, 83, 90, 94, 95, 101-110]. Overall, the preterm delivery rate generally approaches $14-37 \%$, but the frequency is as high as $75 \%$ when the maternal illness is severe. The study of Andrikopoulou et al. posed an exception to this with a preterm rate of just over $1 \%$ [28]. Others have not found an association of preterm birth and infection [61]. Gulersen and colleagues determined that the preterm birth rate during hospital stay was lower among those pregnancies 
where mothers were first diagnosed with COVID-19 during earlier preterm periods [101]. They also found that the majority of early preterm infections fared well and were eventually able to return to their homes. The latter findings were also duplicated by Cosma et al. [11]. Barbero et al. found no difference in preterm delivery whether patients were admitted to hospital or not [29]. As well, some have recorded a high rate of preterm labour [3]. Although premature rupture of membranes has been cited for some, it is not clear at this time that SARS-CoV-2 infection is a cause [110-114]. Co-morbidities among pregnant patients with COVID-19 infection are common [115]. Co-morbidities are very common, however, in those with more aggressive illnesses, and these have especially included obesity and diabetes $[1,2,12,14,19,28,30,31$, $33,34,38-40,42,68,79-81,88,89,94,96,105,110,116]$. The anticipation of potential complications or the advanced nature of disease has led to a high rate of Caesarean section $[1-3,10,21-23,25,29-32,35,38-42,51,55,56,59,60,68$, 74-77, 82, 87, 94, 101, 105, 107, 109-115, 117-129]. The frequencies of the latter have ranged $20-100 \%$. These frequencies are very much geographically influenced by the pattern of medical practice, and the rates have proportionately decreased over time as familiarity with disease potential in pregnant women has emerged. Not all such surgical deliveries however were directly attributable to COVID-19. Some Caesarean sections were prompted by various maternal complications. Barbero and colleagues found a higher rate among patients admitted to hospital initially [29]. They also found increased rates of Caesarean sections and preterm birth compared to uninfected pregnancies. One large study of neonatal outcomes did not find a difference in section rates for infected and non-infected pregnancies [61]. The latter is a reminder that outcomes can be population specific, have multiple covariates, and may be affected by the time course over the duration of the pandemic.

We are reminded that routine vaginal deliveries are nevertheless often successful [130]. The burden of evidence however must be taken to impress the medical and lay communities that disease in pregnancy is sufficiently severe for some such that prevention is clearly desirable. This is especially true when it has been realized that antiviral therapies of variable choice have not been associated with improvements in outcome in this context [1]. The potential for an effective antiviral nevertheless has promise and continues to be studied widely. Apart from tissue pathology, several have also alerted the medical community to the psychological consequences of infection in pregnancy [70, 131-134].

\section{Diagnostic Dilemmata}

Diagnosis of maternal infection has depended largely on genetic amplification technologies which identify the presence of viral RNA in a clinical sample. Although technologically reproducible and widely available, detection of viral RNA does not necessarily equate to the presence of infectious virus, perhaps as would the detection of virus by culture. As disease progresses, it is much easier to detect viral RNA even if the virus presence is non-infectious. Some have proposed a correlation of viral quantitation with measured viral RNA load, but diagnostic assays may have variable determinations for positive tests depending on the details of assay performance [135]. Thresholds for the determination of positive genetic amplifications are also variably applied. The result of a molecular diagnostic test is only as good as the quality of the specimen submitted. Variation may also occur depending on the site of acquisition, and such variations may be seen when the samples are from different respiratory tract sites. From a confirmatory perspective, research studies can utilize sequencing of amplified products or secondary confirmatory amplification tests to validate initial findings. Another such approach is to re-perform genetic amplification with a different set of virus targets. Commercial diagnostic assays for viral RNA are usually supported by studies which produce validation data using common samples such as those of the respiratory tract. Although liberally used to assess for viral RNA in many other body fluids or swabs, standardization for nonrespiratory sampling is often lacking. Bertino et al. illustrate the use of control genome template in the context of testing breast milk samples [136]. Thus, although positive results may have secondary confirmatory tests to garner credibility, the specificity of negative results may be less certain if the samples are non-respiratory ones. Further research is yet required to resolve this issue definitively. One must also consider that some patient series have included both laboratoryconfirmed and clinically suspect patients [3, 117].

Given the potential for diagnostic respiratory or other specimens to be collected either overly early or late, there is also the potential to miss a positive diagnosis based on viral RNA amplification or culture [137]. There is thus a potential role for serodiagnostic assays to provide support for viral infections retrospectively [117, 138-141]. Serodiagnosis can be complementary to other methods or can be used alone as the circumstances require. For the determination of fetal infection, a time-honored approach could be the determination of IgMvirus specific antibody in newborn immediately in the postnatal period [52]. IgG-based serology for the newborn may be difficult to use since maternal IgG is capable of nonspecifically crossing the placenta for much of late pregnancy $[73,117$, 142-145]. Confirmatory or immunoblotting techniques would be useful to validate the likelihood of positive serodiagnoses in the research context at least. Zeng et al. found two newborns with anti-SARS-CoV-2 IgM and raised concern for vertical transmission [140]. There were no confirmatory tests, and the offspring were not reportedly ill. Dong et al. also found a newborn with serum IgM reactivity, but no illness arose and again there were no confirmatory assays [138]. 
$\mathrm{Wu}$ et al. found two newborns with reactive IgM and IgG; one had serology taken on day 1 post-birth when an active infection was evident, but the other had serology taken late on day 28 and was ill much earlier [116]. Correia and colleagues showed that IgG and IgM in a newborn followed shortly (15 days) after the onset of a late term congenital infection [52]. Similar findings were also noted after another putative vertical transmission [146]. During the first trimester infections, maternal SARS-CoV-2 antibody was found among some women but not consistently so [18]. Edlow et al. provided findings of cord bloods harboring $\operatorname{IgG}$ antibodies to both the viral receptor binding domain and nucleocapsid for a small majority [73]. As for other virus infections, a one-size fits all laboratory approach to maternal-fetal diagnosis is not always possible [147].

\section{Foci of Virus Excretion}

Excretion of infectious virus from the respiratory tract is wellestablished in SARS-CoV-2 infections. The pattern is similar to that previously known for SARS-CoV and MERS-CoV and represents an obvious route to infect the newborn from an ill mother whether from aerosols or direct contact contamination. What is not as well understood is the potential for other routes of infection. SARS-CoV-2 RNA has been found in blood, urine, stool, and vagina, but it was not consistently clear if these routes could carry infectious virus that could be an infectious risk [41, 148-158]. Anecdotes of live virus isolation from stool have been cited, and thus enteric contamination of the vagina and newborn is plausible $[154,159,160]$. Some have found a correlation of viral RNA quantitation in blood with the severity of clinical disease, and hence the potential for bloodborne direction to the placental interface must be accepted [150].

Precedence for coronavirus presence in the vagina was published by Gagneur et al. [161]. In the context of assessing pregnancies for coronaviruses generally, endemic respiratory human coronavirus 229E was found in vaginal samples with genetic amplification. Some of these mothers were also found to have $229 \mathrm{E}$ in respiratory samples. SARS-CoV-2 had not been found among serum, urine, or vaginal samples from pregnant women with genetic amplification from some reports albeit the numbers assessed were small [41, 52, 90, 95, 162-169]. Edlow et al. however did not find maternal viremia in a larger infected cohort [73]. That the virus could possibly exist in these sites would not be surprising among some infected females knowing that live virus can be present in the bowel and rarely in urine and given the experience had with other coronaviruses and enteric excretion [48, 152, 170]. Furthermore, the finding of coronaviruses in the female genital tract might also be ascribed to direct contamination from skin and hands. Thus, there is ample opportunity for infection to be spread to a newborn from a maternal source. Of note, however, Qiu et al. did not find SARS-CoV-2 in vaginal samples from infected postmenopausal women despite the presence of severe illness [171]. Carosso et al. provided evidence that a newborn could transiently acquire the virus (viral RNA) at the time of birth via the maternal intestinal source [142]. Spread from healthcare workers and the immediate patient environment must also be considered [172, 173]. The finding of viral RNA in vagina, placenta, and fetal and newborn surfaces must also be guarded as an indication of infection if actively infected mothers maintain such viral RNA in their blood which could contaminate the latter specimens. Tainting of a newborn with maternal blood would not be uncommon. Likewise, viral RNA in maternal urine could also complicate the validity of samples that could be tainted from that source.

\section{Epidemiological Parameters}

The epidemiology of spread for coronaviruses has been studied considerably [172]. In addition, SARS-CoV-2-specific epidemiology is rapidly becoming exposed. For pregnancies as in the general population, sentinel points of SARS-CoV-2 contact are often unknown $[1,26]$. The development of asymptomatic infections in pregnancy is now appreciated [1, $2,15,26,30,32,37,39,41,56,61,71,73,75,77,81,104$, $114,118,119,123,127,173-178]$. Screening for temperature on admission to healthcare settings far from guarantees that an infected mother will be detected $[26,175,177]$. The latter provides unknown risk for spread to newborns, family, healthcare workers, and others. The latter also provides concerns for extending environmental burdens of the virus in healthcare facilities. Presymptomatic transmission is inevitable therefore for those that eventually do develop symptoms or signs of infection [172]. For patients generally, Jing et al. have suggested that presymptomatic patients may be responsible for secondary infectivity equal to or more than symptomatic patients [179]. What is not clear is whether pregnancy allows virus to be shed for longer periods of time compared to the general previously-well population when they become infected. Molina et al. offer one example where viral RNA shedding from the respiratory tract could be found for over 100 days from an initial positive test [180]. Although live virus shedding typically occurs for less than one week for most infections, outliers to the latter are likely to extend to over 2 weeks albeit uncommon [181]. There is little reason to believe that the latter should be any different for pregnant patients. Among patients with SARS, urinary and enteric excretion of virus past two weeks were established [182-184]. From yet another perspective, viral genome can be found in the blood of patients especially with correlates to severe disease and outcome [185]. Conceivably if any such represents the corporal dissemination of live virus, it would be credible that infectious virus should reach the placenta on the maternal side and place itself 
to position for transplacental crossing as a breach in the physical barrier would allow. SARS-CoV-2 specific data, to include studies that observe infectivity and measure live virus, continue to be desirable for pregnant and infected patients $[181,186]$.

\section{Antenatal or Neonatal Infection with SARS-CoV-2}

\section{The Search for Intrauterine Infection}

The potential for small viruses to penetrate the placental barrier from the maternal bloodstream poses some initial theoretical concern for SARS-CoV-2 antenatal infection. Studies which have searched for such infections are now emerging although relatively few have been highly detailed in their diagnostic assessments. Some studies have found no viral RNA in amniotic fluid, cord blood, newborn blood or cerebrospinal fluid, meconium, and placental tissue $[3,41,59,73,79,82$, $90,111,112,121,126,142,149,162-166,176,180$, 187-197]. Fetal samples taken at autopsy also proved negative in a few assessments [79, 187]. There is no consistent teratogenic effect observable among offspring of infected mothers [198]. Antenatal infections of major consequence in other virus systems would typically occur well before birth and are generally more worrisome for the first and second trimesters. Stillbirth could not be directly attributed to fetal COVID-19 infection for most studies [2, 13, 50, 55, 76, 79, 125]. Others have found fetal demise for seven citations ranging from 20 to 37 weeks gestational age, but fetal sampling did not have evidence of viral RNA [37]. One large American cohort study found a frequency of $2.2 \%$ for infection-related pregnancy loss [71]. Another American cohort study found that infected mothers had three times the incidence of stillbirth compared to controls [81]. Some fetal deaths are likely to be directly attributable to the consequences of severe maternal infection [12, 31]. A large multinational prospective cohort review found that neonatal deaths were prematurity-related rather than infection-related [13]. Pique-Regi et al. provide a theoretical argument against the likelihood of frequent transplacental spread by the finding that, throughout the pregnancy, the placenta is relatively deplete of the ACE2 receptor binding domain for SARS-CoV-2 [199]. As well, they found that the placenta is relatively deplete of TMPRSS 2 which is the serine protease associated with virus cell entry. Hecht et al. place a somewhat different view of the latter [125]. They found $A C E 2$ expression polarized to membranous stromal regions of syncytiotrophoblasts as well as cytotrophoblasts and extravillous trophoblasts. They also determined that TMPRSS2 was weakly present in the villous endometrium and syncytiotrophoblast. Other publications support the latter $[73,200,201]$. Lü et al. found that both trophoblast and fetal lung alveolar cells are very low in ACE2 expression, but high levels of expression were found in multiple other fetal tissues [202]. Jing and colleagues provide an alternate model for vertical transmission [203].

Despite the above, there are yet other citations that raise some concern about the potential for congenital infections albeit overall reports are conflicting [204]. Zamaniyan et al. found viral RNA in an amniotic fluid during Caesarean section in a pregnancy of 32 weeks gestational age whose newborn was also positive for viral RNA but asymptomatic [98]. Viral RNA on placental membranes and in placental tissue within 30 min of birth has been found [152, 205]. Viral RNA has also been found in one episode on the fetal side of the placenta in combination with inflammation of the umbilical cord substance $[152,187]$. In the context of two newborns with positive assays for respiratory SARS-CoV-2, virus was found on the fetal side of the placenta with in situ hybridization [206]. Despite the latter, however, both newborns did not develop symptomatic disease. No serological assays were performed, and the findings were made for two of 22 births from mothers with COVID-19. One case report, for an ill female of 28 weeks gestation who was delivered by Caesarean section, found evidence of virus in the placenta through electron microscopy [207]. There was also decidual vasculopathy, but confirmatory assays for the virus were lacking. In this context, one must be cautious about the interpretation of virus morphology alone given past difficulty with the same [48]. Mulvey et al. did not find viral RNA or spike protein in the placenta with special stains, but reported evidence of fetal vascular perfusion defects [208]. Shanes et al. also placed a different perspective on placental pathology and found that placental changes during COVID-19 are more likely to reflect features of generalized maternal vascular compromise [209]. Such a thesis is credible given the vascular events including coagulopathy that occur for many patients, let alone pregnant ones, during severe infections [210,211]. The publication of Shanes et al. did not however detail viral studies [209]. Other investigators also found some placental pathology mainly consistent with vascular compromise [3, 212, 213]. In the small series reviewed by Menter et al., evidence of both fetal and maternal malperfusion in placental tissues was suggested [214]. Inflammation in the latter study included villitis and intervillositis. Hsu et al. cite hypertrophic arteriopathy, subchorionic laminar necrosis, and chronic villitis in a placenta of an infected term mother whose offspring did not develop disease [215]. Immunohistochemistry of the placenta for SARS-CoV-2 nucleocapsid antigen revealed diffuse placental presence including trophoblasts. Others found placental macrophage infiltration in the absence of vasculopathy despite placental abruption, but SARS-CoV-2-specific antibody staining gave evidence of localization predominantly to the syncytiotrophoblast cells [54]. Ferraiolo et al. indicated that several placental swabs were positive for the same 
asymptomatic pregnancy, but placental pathology included only some fibrin deposition and intervillous hemorrhages [216]. The newborn was not infected. Nevertheless, regardless of whether fetal or newborn infections have occurred, it is prudent to routinely assess the placenta for pathology when maternal infection has been documented [217]. Blauvelt et al. found evidence of acute chorioamnionitis in one citation [69]. For a single suspected vertical transmission in a large observational cohort, massive chronic intervillositis was found [61]. Others did not find placental pathology among several infections $[67,111,112,121]$. Liu et al. did not find differences in the frequency of chorioamnionitis among infected and control patients albeit the comparison groups were small [126]. In the context of a maternal death, placental pathology was also not found by others [97]. Of particular note, Gulersen et al. did not measure statistically significant differences in placental pathology for those patients who were infected versus historical controls [60].

In a prospective study from New York, fetal vascular malperfusion and fetal vessel thrombi were found in up to $\sim 50 \%$ of infected mothers which was much different from $\sim 11 \%$ in controls [37]. Meconium staining, suggestive of fetal/newborn stressors, was also much more common on the placentae of infected mothers. Remarkably, however, there was no significant difference between infected and non-infected mothers for evidence of histological chorioamnionitis or chronic villitis. In their assessment overall, the lack of finding viral RNA among newborns was more supportive of vascular compromise rather than direct fetal or placental infection. The findings of Hecht et al. are also supportive of the latter in that there was no characteristic pathology in placentae from infected mothers [125]. The majority of placentae did not have evidence of viral RNA or viral protein. Only 2/19 placentae were found to have viral RNA and with localization to both syncytio- and cyto-trophoblasts.

A more suggestive anecdote of possible intrauterine transmission was that reported by Sisman et al. [218]. A newborn was delivered vaginally at 34 weeks and developed fever and respiratory illness on day 2 . A nasal sample yielded a positive RT-PCR assay at $24 \mathrm{hrs}$. of life. Although one could speculate that the virus may have been acquired at birth through a contaminated vagina, histopathology of the placenta was very suggestive of localized infection, and there was also evidence of meconium staining. Immunohistochemistry gave evidence of virus presence in syncytiotrophoblast cells, and virus was found by electron microscopy within the same cells. Therefore, if transmission occurred antenatally and to cause symptomatic infection shortly after birth, the virus would likely have been transmitted very near the vaginal delivery. Schwartz et al. cite an example of virus detection in amniotic fluid [219].

Kirtsman et al. also provide strong evidence for late intrauterine transmission [152]. A newborn of 35 weeks gestational age was born to a symptomatic mother by Caesarean section in the context of presumed intact membranes. The newborn had viral RNA detected at the time of surgical delivery, and multiple samples of the placental tissues, both fetal and maternal aspects, yielded positive samplings. Placental pathology was also very suggestive of active inflammation by the finding of chronic histiocytic intervillositis.

Another convincing report of late vertical transmission was described by Vivanti et al. [89]. An infected newborn was delivered from a symptomatic mother at 35 weeks gestational age by Caesarean section on account of presumed fetal compromise. Despite intact membranes, viral RNA was detected in the amniotic fluid, neonatal throat and rectum, neonatal blood, and placenta. The placenta had evidence of diffuse fibrin deposition, infarction, and acute and chronic intervillositis. The inflammation was comprised of CD68+ histiocytes, and viral presence in perivillous trophoblasts was identified by immunohistochemical analyses. Late vertical transmission was also likely in the report of Correia et al. where a symptomatic mother delivered a newborn whose blood and respiratory samples were positive for SARS-CoV2 [52]. The offspring was acutely symptomatic with moderately severe respiratory disease and acidosis. Live virus was cultured from the respiratory tract shortly after birth, and the newborn developed seropositivity (both $\operatorname{IgG}$ and $\operatorname{IgM}$ ) within two weeks of the illness.

Gupta and colleagues found evidence of virus acquisition vertically from a mother who was symptomatic for a considerable period prior to birth [146]. The newborn delivered at 29 weeks gestational age and was already symptomatic with advanced respiratory disease and acidosis at delivery during caesarean section. The newborn also seroconverted after 2 weeks with both IgM and IgG antibody. Placental pathology revealed acute and chronic villitis, intervillositis, and placenta hemorrhage and fibrin deposition. Hinojosa-Velasco et al. found virus in respiratory secretions and stool of a newborn at delivery from Caesarean section, and the infant suffered respiratory distress at the same time [165].

Shende et al. showed proof for vertical transmission during the first trimester of one pregnancy where the mother had been asymptomatic [220]. There was fetal demise found approximately five weeks after maternal infection, and the fetus clinically showed hydrops. Amniotic fluid tested positive by RNA amplification. The placenta showed considerable pathology, and immunohistochemistry localized virus proteins to syncytiotrophoblast and villous stroma.

Facchetti et al. reviewed fifteen placentas from infected pregnancies [221]. The placental pathology, if any, was variable and included vascular thrombi, placental infarction, chorioamnionitis, hematoma, fibrin deposition, and/or funisitis. Mononuclear cell infiltrates stained commonly for CD68+CD14+CD163+. One particular pregnancy of 37 
weeks gestation was delivered vaginally due to maternal complications. The newborn developed respiratory disease in the first 24 hrs. of birth but did not have confirmation of viral RNA excretion until 2 days later. Placental examination for the latter showed viral presence on both maternal and fetal aspects by a variety of methods. Inflammatory infiltrate was evident. The authors posed these findings as being indicative of vertical transmission. From this and other reports, it appears that many of the proposed vertical transmissions so published have occurred late in pregnancy.

Debelenko et al. compared the pathology of 75 placentas from infected mothers to 75 control placentas [222]. There was meagre evidence of significant differences between groups, and there was no confirmation of vertical transmission. It must be emphasized however that the infected cohort had existing or pre-existing very mild disease. Subtle differences among groups often did not reach statistical significance. One placenta had evidence of placental viral invasion despite no evidence of disease in the newborn. Virus was identified by immunohistochemistry in the syncytiotrophoblast where there was also evidence of cellular injury, intervillous inflammation, and infiltration by CD68+ cells. Of note, 74 of 75 placentas from infected mothers with such mild illness did not have evidence of viral infiltration of the placenta. A similar lack of placental infection was also found by Edlow et al. [73]. The latter investigators did not find any characteristic placental pathology for COVID-19 but did see evidence of placental malperfusion which correlated somewhat with increasing disease severity.

Schwartz and Morotti have collated a review of placental pathology and its association with infection [219]. Adhikari et al. examined a large series of placentas from COVID-19 infections and could not find an association of increased pathology with various stages of maternal disease severity [61]. They also found, however, that pregnancy loss was associated with severe disease in early ( $<37$ weeks) gestations even though no stillbirths per se were seen in their large cohort.

Garcia-Manau and colleagues detail of two fetuses that developed transient skin edema during maternal COVID-19 infections at 20 and 22 weeks gestation [223]. These clinical manifestations resolved as did the maternal respiratory illness. In each case, amniotic fluid and peripheral blood did not have evidence of viral RNA. Majachani et al. portray an episode of late congenital infection in an offspring born to an HIV-positive mother [58]. Of a mother with severe compromise from COVID-19, a newborn was found positive for viral RNA and developed pneumonia and acidosis [224]. The latter newborn however did not convert with IgG reactivity over 21 days. Early infection occurred in a newborn from a vaginal delivery where maternal-newborn contiguity was abrogated [225].

The detection of viral IgM in the newborn at birth would be suggestive of intrauterine infection $[188,226]$. Despite the latter, early neonatal manifestations of infection were not detailed nor was there description of complicated maternal illnesses. Wu et al. found neonatal IgM and $\operatorname{IgG}$ in a newborn shortly after birth who was symptomatic; the latter was re-reported from Dong et al. $[116,138]$. He et al. make similar findings in a small cohort [188]. Marzollo et al. detail very early newborn deterioration with respiratory acidosis and likely pneumonia that required ventilator support [227]. The latter infant was born to a mother near term who suffered a febrile illness some 9 days prior to vaginal delivery in the context of presumed intact membranes. At best, the latter would represent very late in utero transmission. In a large review, Cavicchiolo and colleagues did not find evidence of significant serological responses among newborns of infected mothers [228]. Similar findings were made for a newborn reported by Toner et al. whose mother was infected at 27 weeks gestational age; delivered at 33 weeks, both intrauterine and newborn cord blood did not yield anti-coronavirus antibody even though antibody to rubella and varicella-zoster virus could be detected [229]. Blauvelt et al. did not find either IgG or IgM in the blood of the preterm newborn [69]. In contrast, others have found newborn IgG but not IgM in an infant born at 38 weeks gestational age whose mother was infected at 29 weeks [143]. In utero transplacental passage of $\operatorname{IgG}$ in any regard occurs more readily as the placenta matures.

It must be concluded that intrauterine infections are not common, but further data in this regard continues to be welcome. For congenital malformations arising as a consequence of early infections, no such association has been found [13].

\section{Neonatal Infections}

Coronavirus infections as generically defined by electron microscopic findings were believed to have occurred in neonatal intensive care and in outbreak fashion causing neonatal necrotizing enterocolitis [230-232]. Culture-confirmation of such outbreaks was then lacking. In this regard, it is of interest that $\mathrm{Wu}$ et al. have described three near-term newborns who developed necrotizing enterocolitis in the context of maternal COVID-19 [116]. Cooke and colleagues detail a premature newborn who developed a bowel perforation and required a bowel resection, although it was likely that the complications were connected to prematurity [70]. Human respiratory coronavirus OC43 was found to have caused an infection in an infant in the first 3 weeks of life, but there was no discussion of the mechanism of acquisition [233]. In the latter study, prolonged viral RNA shedding was found for OC43 and NL63 in other children less than one year of age. Gerna et al. cited infections with OC43, NL63, and 229E among infants ranging from 12 days to 2 months of age [234]. Gagneur et al. diagnosed infections in neonatal intensive care, but given the delayed onset, nosocomial acquisition seemed likely [235]. Sizun et al. also found newborn infections, but sources of infection were indeterminate [236]. 
In a large American cohort, perinatal COVID-19 infection was estimated at 2.6\% [108]. Most studies, however, report an infrequency of neonatal SARS-CoV-2 infection at birth or thereafter despite maternal infection of varying severity $[1-3,13,16,19,20,22-25,29,30,35,38,41,42,46,47$, 51, 55, 59-61, 66, 68, 72, 82, 90, 100, 104-107, 109, 110, $112,113,117-120,123,126,128,129,139,162,168,185$, $188,191,193,196,197,213,222,228,237-244]$. The latter has also been evident despite some newborn exposure to maternal breastfeeding [82, 118, 127, 136, 241]. In a small series, Cojocaro et al. did not find newborn infection regardless of whether infants were bonded with mothers after birth [244]. Apart from respiratory specimens, these newborns have at times been sampled for meconium, gastric aspirates, cord blood, urine, and feces. Newborn deaths in this context were not directly attributable to COVID-19 infections [34, 55, 77, $78,94,149,245]$. Some have been admitted to newborn intensive care, but disease has often not been definitively attributed to viral infection [38, 55, 94, 124, 239, 245-249]. Newborn infection may be asymptomatic $[32,58,118,136$, $250,251]$. Among a large collection of pediatric data throughout China, the infection of newborns under the age of 29 days constituted $0.7 \%$ of all infections [252]. Complications among these newborns commonly occur, but it is more often attributable to non-viral mechanisms [128]. Schwartz et al. mentioned two newborn deaths among those of a retrospective cohort study in Iran, but there are no details to confirm that the infection was the direct or indirect cause of death [95]. Another report from Iran found that $28 \%$ of newborns acquired SARS-CoV-2 from their infected mothers [40]. Liu et al. examined the immunological profiles of uninfected newborns from infected mothers and did not find significant aberrations [240]. One must however keep in mind the potential for in utero compromise to arise out of placental dysfunction. Severe maternal infection may be associated with newborn complications or earlier birth [253]. Nayak et al. did not find differences in Apgar scores for newborns from infected or non-infected mothers [21]. In a collation of forty-six children with COVID-19 under one year of age in Wuhan, China, five newborns within 0-7 days of birth were said to have been affected, but details of these were not reported [254]. As for older children and adults, asymptomatic infections of newborns do occur [255]. Zamaniyan et al. cite a possible vertical transmission in the context of a well newborn [98].

Citations of newborn infection have emerged on the basis of positive findings of viral RNA [21, 32, 34, 40, 52, 76, 94, $95,127,136,152,218,227,245,256-260]$. As for maternal infections, viral RNA may be detected for a considerable period of time after infection onset [260]. Some of the positive samples were obtained from the newborn in the first $12 \mathrm{~h}$ of life. Occasional newborns have been ill immediately after birth [2, 95]. The positive diagnostic assay was established among some $2.3-7 \%$ of those born to infected mothers.
Savasi et al. found four of 57 newborns positive for viral RNA, but none of them developed obvious disease [87]. Nayak et al. found three of 131 newborns positive on initial screening, but none of the three were again positive on postnatal day five [21]. No disease among the latter newborns was evident. In India, newborn infections were mild and selflimited [258]. The latter studies are contrasted to the report from Farghaly et al. who found that newborns of COVID-19 infected mothers were more likely to have desaturations, have poor feeding, and be symptomatic during the first 2 weeks of post-natal follow-up [237]. Virus can be potentially found in both respiratory secretions and stool [260].

Symptomatic infections have occurred, but it must be understood that some suspect infections are not confirmed by diagnostic studies [102]. Disease may affect the respiratory tract, the digestive tract, or both [260]. After separation from a mother post-vaginal delivery, newborns have developed an episode of respiratory disease $[75,95,152,227,245,256,261,262]$. Gale and colleagues report a varying spectrum of neonatal COVID19 in a large prospective national surveillance in the UK [245]. Fernández Colomer et al. confirm a variable but relatively mild spectrum of disease including upper respiratory symptoms, apnea, fever, respiratory distress, and gastrointestinal symptoms [250]. Regardless of where the infection was acquired, a sizable proportion of these patients required new or continued hospital admission and the provision of supplemental oxygen. Length of hospital stays for community-acquired infections ranged 2-6 days. The report of Kirtsman et al. is highly suggestive of late vertical transmission, and the newborn had evidence of viremia in a plasma sample despite having a relatively mild clinical illness [152]. One newborn had a positive assay on postnatal day two but was not ill thereafter [83]. Some infants developed symptomatic respiratory infection by days 4-15 [76, 260, 262-267]. Four other newborn infections appeared to have occurred despite maternal Caesarean section and physical separation [261, 268]. The risk of nosocomial acquisition is real although suggested to be low [245, 260]. Respiratory infections occurred within 2 days of birth. A neonate developed presumed COVID-19 respiratory illness, but the infant had considerable pulmonary complications arising from prematurity (26 weeks) as well [269]. A near similar complicated lung disease and infection were detailed by Gordon et al. [270]. Alzamora et al. describe a pre-term birth from Caesarean section in which the newborn was immediately separated from the mother but where the infant developed an illness in the first $16 \mathrm{~h}$ of life [271]. They postulated a potential vertical transmission to account for the acute illness after delivery. It was not clear whether respiratory distress was solely attributable to COVID-19 in the latter report given the degree of prematurity. Hopwood et al. found a term newborn to be seemingly infected in the first $25 \mathrm{~h}$ of life and decompensation included severe respiratory failure [257]. The mother may have had ruptured membranes for several days prior to vaginal delivery. Demirjian et al. had a 
laboratory diagnosis for a newborn at day 3 who became ill by day 5 [149]. They speculated on a vertical transmission given that the baby had been delivered by Caesarean section and had been segregated from mother fastidiously at birth. Two newborns screened negative for viral RNA at birth proved to have positive respiratory samples on day 2 after birth [19]. One of the latter developed what was called a 'viral pneumonia'. A possible newborn infection was also reported by Yu et al. [272]. There are few convincing reports of fulminant respiratory illness nor severe systemic complications after newborn infection. Regardless, severe disease in older pediatric populations has been cited, and therefore it is justified to closely follow the newborn age group as well [273]. Anecdotal reports of COVID-19 late-onset newborn infections between days 4 and 90 have been published, and the patients have fared well in resolution [29, 245, 250, 256, 259, 265, 266, 274-278]. The need for intensive respiratory care in such lateonset infections is uncommon [259, 265]. A report from Spain provided a broad experience in which post-natal infections occurred for newborns with ages 7-43 days [250]. The latter included considerable numbers of both community-acquired infections and nosocomial infections. Two reports provided evidence for a newborn febrile neurological presentation [262, 274]. Whether asymptomatic or symptomatic, it is not known if a small proportion of newborns, whether with co-morbidities or not, will prove to be sources for prolonged or chronic shedding of the virus.

Viral co-infections seem to be uncommon for newborn patients with COVID-19 [250].

\section{Maternal Management and Prevention}

\section{The Burden of Presenting Infection}

The pattern for managing maternal patients before, during, and after births can be expectedly variable given the different health care contexts. It is much easier to garner consistency when the maternal healthcare unit is larger and where policies are more widely repeated. The first understanding of disease potential begins at intake. For those with planned interventions and deliveries, a pre-presentation screening process will have some benefit. The latter can include screening history prior to site visitation for fever, illness, or contacts. The patient may also be screened for potential infection at the time of ad hoc presentation to a care facility. The intensity of the latter should depend on the prevalence of COVID-19 in the given geography [26, 242]. Those presenting with asymptomatic infection will pose difficulty, and it should be widely taught that some patients will first raise concern for infection after entry into the healthcare setting. Furthermore, it is well understood that laboratory results are returned over a variable window of time which then places more burden on those admitting the patient.
For those mothers who are known SARS-CoV-2-positive or highly suspect, immediate triage to isolation is imperative, and staff will require personal protective equipment. Confines to a negative pressure room is desirable. In absence of the latter, single room occupancy is essential in the least. Apart from infection control measures taken by staff, the mother can be encouraged to wear a mask during the time of personnel or visitor entry. Mask use is also prudent during patient transport.

Regular entry viral screening has its merits, but such a routine will again depend on the prevalence of disease in the community [2, 15, 26, 32, 139, 173, 175, 279-281]. In one of the latter studies, the frequency of finding viral RNA in a respiratory specimen from presenting asymptomatic patients in Spain was only $0.5 \%$, but yet overall, including known and symptomatic presentations, $8 \%$ of pregnant mothers were infected [175]. In New York, routine screening identified considerable asymptomatic infections [242, 279]. The latter frequencies were occurring during peak pandemic. There is no established rule for determining where the threshold for universal screening should be. Given the timing for laboratory results to return, caution must be applied on an individual basis taking into account the patient's status and the community burden. There is also the possibility that disease may occur later in the patient's admission. Attendees with the mother for a delivery should be minimized and should be clinically screened as well. The patient should be encouraged to wear a mask during delivery. Although viral antigen detection systems have been widely adopted in other contexts, they are reknowned for lacking sensitivity when viral loads are low.

\section{The Burden of Institutional Virus}

The environmental burden of virus in the patient vicinity is potentially considerable [282-286]. Rooms should be minimized for equipment and paraphernalia as feasible. Regular cleaning and disinfection of the patient environment is critical and should observe approaches used otherwise to prevent SARS-CoV-2 transmission between all patients [172]. The use of personal protective equipment should be commensurate with likelihood of aerosol generation during procedures. Operative care prevention should be no less than that used for other operative procedures. Herman et al. have crystallized the anaesthesia care concerns [287]. Visitor limitations should be enforced.

When patients present with known disease, the timing for quarantine should be a minimum of 10 to 14 days, and conservative estimates favor the latter [181, 288]. Some have proposed that consecutive negative diagnostic assays should be sufficient to de-isolate a known positive patient. For example, Shmakov et al. have used the double negative diagnostic assay approach to re-unite newborns and mothers after initial separation [41]. Krupp and colleagues, however, rightfully 
raise concern about the use of qualitative versus quantitative diagnostic assays for the latter [289]. There is also remaining concern about live virus shedding past a two week period [48, $172,181]$. Infection of the healthcare worker has become a major institutional dilemma in the COVID-19 era and potentially a source for infection $[173,250]$. The pointed use of telehealth mechanisms to follow pregnancies is just as relevant as it is for following other aspects of healthcare generally [290]. The role of antiviral treatment in diminishing viral excretion is yet to be realized in a significant manner, and indeed many clinical trials purposely exclude pregnant females [291].

\section{Fetal and Newborn Management and Prevention}

\section{Does the Fetus or Newborn Benefit from Disease Prevention?}

If it is true that antenatal infections are rare and that newborn disease is mild, one might not anticipate much of an impact for COVID-19 apart from maternal disease. The current findings detailed above in regard to placental pathology, however, suggest that severe disease may have a role to play in placental compromise. Any such pathology could have an effect on fetal blood supply and oxygenation that could go unmeasured at birth or thereafter with conventional techniques. Therefore, protection of the pregnant female is the first step to preventing disease for the fetus and newborn. There is also the prospect that disease prevention for the newborn thereafter contributes to curb further spread back to a post-partum maternal cohort, other newborns and their subsequent contacts, and equally important the healthcare worker. As has been experienced early, a general reduction of disease for any specific patient group may go a long way to sparing the needs for personal protective equipment and other resources. Narang et al. detail their experience with the management of fetal surgery during pandemic times [292]. Obstacles to maternal-neonatal care in the COVID-19 era amid a scenario with lesser resources can prove to be an extra-ordinary burden [293].

Nosocomial acquisition of the virus among newborns, especially those with pre-morbid conditions, has been cited $[250,260]$. Although SARS-CoV-2 is generally mild for most newborns, the latter reports illustrate a significant consequential pattern for some. For nosocomial infections, both mother and healthcare worker can be vectors.

\section{Mechanisms to Prevent Disease}

Physical separation of infected mother and newborn can be effective $[120,122,239]$. Whereas the scenario of Caesarean section can be beneficial to assist in the latter, it is not an absolute indication in itself. The need for medical intervention must take into consideration the entire maternal-fetal unit, and discretion is afforded to clinical decision-making as it is also for the method of surgical intervention if needed [100]. A vaginal birth theoretically carries greater risk for contamination of the newborn, and thus, even if separated, late-onset potential for newborn infection, symptomatic or asymptomatic, must be assumed. If possible, physical separation of newborns born to infected mothers from those born to noninfected mothers would be prudent as feasible. In the context of the newborn that may be screened for infection early on, a negative diagnostic assay should be repeated should the infant remain in the healthcare setting. Newborns of known infected mothers or those highly suspect should be screened. A respiratory sampling should be the minimum focus. Given that newborns can be infected, symptomatic maternal illness should lead to newborn isolation until the clinical and laboratory conclusions are otherwise. Concern should most be given to newborns that are premature, compromised, or carry potentially relevant risk factors. De Rose et al. provide their account of necessary changes made to newborn care in a neonatal intensive care unit, whereas others have outlined a proposal for newborn emergency transport in this context [294, 295]. Universal screening of newborns, parents, and healthcare workers in a neonatal intensive care unit has been assessed and has placed the burden of prevalent coronaviral infections on the associated adults [228]. Simon et al. provide a paradigm for the management of neonates from infected mothers [296]. Apart from infection risks, the maternal-fetal unit must also be considered for the various risks of pharmacotherapy including intended anti-SARS-CoV-2 treatments [297]. There is nevertheless some controversy with any one particular approach being mandated for all settings. For example, despite rooming-in and direct breastfeeding, some have found the outcome of newborn infection to be relatively negligible $[35,136,253]$.

If the consensus for whatever approach is that the infected mother and newborn should remain together, preventative hygiene for the mother should be encouraged for the potential value that it may have $[136,241]$. The totality of methods for potential spread are continuing to be better understood [298]. Maternal masking while breastfeeding and distancing within the room should be observed albeit the prevention potential in that context is far from well-known. Enhanced hand hygiene will likely have some role for prevention. It could be argued that skin-to-skin contact from breastfeeding may augment risk, but the overall clinical context should be taken into consideration by patient and medical decision-makers. Attention to maternal mental health may also be warranted especially given its potential impact on adherence to prevention strategies as they may be implemented [243, 299, 300]. Relative isolation of these patients also brings psychosocial problems to the forefront [301]. Maternal emphases of prevention may be variable [302]. 


\section{Controversies with Breast Milk}

One of the matters often raised in either separating mother from newborn or for rooming-in is breastfeeding [127]. The value of breastfeeding for bonding and nutrition is widely accepted. The interruption of the same for prevention measures, although undesirable, requires observation for the resolution of maternal disease and shedding [120]. Whereas the definition of a suitable quarantine time for mother may be a matter for debate, the 14-day rule post-exposure appears to be widely held and is a reasonable minimum. The effect of the pandemic on breastfeeding practices has been variable $[8$, 303]. Perrine et al. illustrate the heterogeneity in the conduct of breastfeeding alone [304]. Ronchi and colleagues found minimal transmission for mother-newborn pairs where breastfeeding was largely allowed [127]. Many of the mothers in the latter study however had been ill for a considerable period of time prior to delivery and may have had a low potential for infectivity.

Apart from nutrition, breast milk is an important source of immunity for the newborn in many regards. Although IgG is transferred to the fetus in utero, secretory IgA ( $\operatorname{sgA}$ ) and IgG in colostrum and milk provide first lines of mucosal protection for the newborn. The common mucosal immune system facilitates the production of $\operatorname{sIg} \mathrm{A}$ in the breast milk that is common to the respiratory tract. Therefore, mothers who have been infected for more than 10 days will likely have some antiSARS-CoV-2 antibody transferred to the fetus during the prebirth or will have anti-SARS-CoV-2 SIgA and IgG in milk; quantities of the latter will be considerably variable [143]. The amount of such acquisition by the fetus or newborn is timeaccrued. As for other viruses, passive $\operatorname{IgG}$ acquired in utero declines in the newborn blood gradually over a 4-8-month period, whereas breast milk sIgA is likely to be secreted over a long period during the breastfeeding course. SARS-CoV-2specific data would be welcome, and preliminary information on newborn antibody presence has recently emerged [163, $226,305]$. One such study did not find differences in neonatal outcome after maternal infections with the presence or absence of acquired IgG antibody [305].

There is some science that supports the role for breast milk in coronavirus prevention. In the bovine model, milk is virucidal for bovine coronavirus in the absence of vaccination [306]. Heating of the milk, including pasteurization, loses some of this virucidal activity, but the loss is not all-or-none. The changes in heated milk may include a partial loss of virusneutralizing activity [307]. In the porcine model, infection results in the production of neutralizing $\operatorname{Ig} \mathrm{A}$ in milk for coronaviruses [308]. Several other experimental approaches have shown the value of coronavirus neutralizing antibodies in breast milk or IgY preparations [309-311]. Taking these observations a step further into the human realm, the classic studies on coronavirus 229E among volunteers from the
Common Cold Research Unit (Salisbury, Wiltshire, UK) should be rekindled [312, 313]. Pre-infection neutralizing antibody gave protection to homologous strains on rechallenge, but susceptibility remained in part to heterologous strains [312]. Both circulating and local mucosal IgA were associated with protection along with other mucosal factors [313]. These data are not only consistent with a post-infection protection at the mucosal site of viral entry, but also provide the potential to help define protective mucosal antibodies for the population as a whole $[314,315]$. With the definition of a reproducible animal model, passive transfer of protective antibody to offspring can now be assessed [316]. Indeed passive immunotherapy has promise for both mother and newborn as may be required [317]. There has been considerable progress in the understanding of protective and passive immunity for COVID-19, and there is considerable potential in the field of maternal immunity from COVID-19 for translational research and potentially practical implementation [318, 319]. Pace et al. have begun such assessments with finding of SARSCoV-2-specific antibody in breast milk; they also have found that virus-directed antibody has neutralizing capacity [320].

\section{Risks from Breast Milk}

Several studies have looked for viral RNA in breast milk, but these assessments lack observation for live virus [3, 38, 46, $53,90,138,142,143,166-168,180,195,240,260,266,269$, $320,321]$. Testing milk well after maternal disease onset may contribute to underestimation. Some of the reports have identified positive samples, although confirmatory tests have been lacking [38, 41, 136, 152, 165, 167, 168, 322]. The review from Bertino et al. details an infant whose breast milk supply was found to have viral RNA twice over a month but where the testing was negative with an interim specimen [136]. There is no evidence yet which confirms that such presence represents excretion through breast milk [323]. More likely, virus entry into milk could be connected to skin contamination and subsequent seeding of milk through breast expression, suction, pumping, and/or hand exposure. In the latter regard, Pace et al. found viral RNA on breast skin samples but not directly in breast milk [320]. If decisions are made for mother and newborn to room-in, the cohort may remain together, but the newborn will risk infection in a context of maternal risk reduction however mild the consequences may be. Regardless, Salvatore and colleagues have presented a scenario where such risk appears to be small given certain precautions [241]. If the mother and newborn are separated, the timing is relatively short for the infant to receive other sources of milk before they are re-united and breastfeeding resumes. There is yet however the opportunity for an infected mother to harvest milk and for it to be fed to the isolated newborn. This approach assumes that collection minimizes milk 
contamination and that vessels for milk are disinfected as they are mobilized to the newborn's venue or beyond.

In respect of the above, heat sensitivity of SARS-CoV, MERS-CoV, and SARS-CoV-2 is known [172]. It is quite likely that several approaches to heat treatment of potentially infected maternal milk will inactivate infectious virus, including pasteurization [324-327]. The study of Chin et al. assessed heat inactivation in the context of the protein load of tissue culture medium [327]. Unger et al. have recently shown that Holder pasteurization $\left(62.5^{\circ} \mathrm{C}, 30 \mathrm{~min}\right)$ reasonably inactivates SARS-CoV-2 [328]. Heat treatment of milk has otherwise been considerably analyzed [329-339]. At pasteurization temperatures, there is some loss variably of endogenous lysozyme, lactoferrin, lactoperoxidase, and IgA, but the reductions are only partial. Thus, an effective approach for heat-treating infected mothers' milk and eradication of viable virus along with the retention of many nutritious and protective factors is in reach. This would allow an infected mother to donate milk to her newborn after heat treatment if all precautions otherwise are maintained.

\section{A Model for Care?}

There is no approach to the management of COVID-19 for obstetrical care that will be perfect given the variations on clinical presentation, healthcare availability, and associated pressures of dealing with potentially large numbers of contacts and infections. Such variation is evident from the many care and prevention guidelines thus far posted [340-342]. Sharma and colleagues detail key considerations in a setting where maternal infection numbers are considerable [343]. All of these authorities are wary of the changing and cumulative information that is quickly arising and with which alterations to such guidelines will be incrementally made. We must certainly consider that SARS-CoV-2 could become the fifth common endemic respiratory coronavirus that will persist despite vaccination and/or widespread infection [344]. The concept of herd immunity does not necessarily impart absolute protection if the virus becomes established, but an associated mitigation for subsequent secondary illnesses is possible.

There are many similarities to guidelines previously had for prevention of other obstetrical and perinatal infections especially from respiratory viruses. We can generally accept that maternal infection can be sufficiently severe and frequent that prevention is imperative. As it is essential to contain the COVID-19 pandemic, secondary spread is a focus that must also be especially considered. Until either effective prevention or treatment chemotherapy is available or until effective vaccines arise and considerably mitigate and prevent disease, we need to provide an environment of safety for mother, fetus, newborn, contacts, and healthcare workers with the best of science and experience that exists.

\section{Key Concluding Themes}

In summary, the following statements summarize the current state of knowledge:

- Maternal COVID-19 infections commonly occur.

- The spectrum of maternal infection is considerably variable and includes both asymptomatic infection and advanced multisystem disease with potential for maternal demise.

- The propensity to severe maternal disease is often associated with co-morbidities.

- COVID-19 in pregnancy is associated with preterm delivery and a higher incidence of Caesarean section delivery.

- Maternal infections have risk for placental vascular abnormalities with potential adverse outcome for the fetus.

- Congenital infection is likely but occurs in very much a minority of infected pregnancies and more so near term.

- Most maternal infections do not result in subsequent newborn infection.

- Newborn infections occur both early and late, and disease manifestations are generally mild if they occur.

- Both infected pregnancies and infected newborns can serve as vectors for further SARS-CoV-2 transmission.

- Prevention in the maternal-newborn context must consider the specific healthcare context, depend on the prevalence of infection in that population, and should be sensitive to both caregiver and patient priorities.

Acknowledgements This paper is dedicated to the memories of John and Tora Anderson whose support and kindness sparked a career dedicated to infection control and human health.

Author Contribution One sole author

Data Availability Not applicable

Code Availability Not applicable

\section{Declarations}

Ethics Approval Not applicable

Consent to Participate Not applicable

Consent for Publication Not applicable

Conflict of Interest The authors declare that they have no conflict of interest.

\section{References}

1. Li N, Han L, Peng M, Lv Y, Ouyand Y, Liu K, et al. Maternal and neonatal outcomes of pregnant women with COVID-19 
pneumonia: a case-control study. Clin Infect Dis. 2020 ciaa352. https://doi.org/10.1093/cid/ciaa352.

2. Maraschini A, Corsi E, Salvatore MA, Donati S. and the ItOSS COVID-19 Working Group. Coronavirus and birth in Italy: results of a national population-based cohort study. Ann Ist Super Sanita. 2020;56(3):378-89.

3. Chen H, Guo J, Wang C, Luo F, Yu X, Zhang W, et al. Clinical characteristics and intrauterine vertical transmission potential of COVID-19 infection in nine pregnant women: a retrospective review of medical records. Lancet. 2020;295(10226):809-15.

4. Rios-Silva M, Murillo-Zamora E, Mendoza-Cano O, Trujillo X, Huerta M. COVID-19 mortality among pregnant women in Mexico: a retrospective cohort study. J Glob Health. 2020;10(2): 020512. https://doi.org/10.7189/jogh.10.020512.

5. Suleyman G, Fadel RA, Malette KM, Hammond C, Abdulla H, Entz A, et al. Clinical characteristics and morbidity associated with coronavirus disease 2019 in a series of patients in Metropolitan Detroit. JAMA Netw Open. 2020;3(6):e2012270.

6. Kronbichler A, Effenberger M, Eisenhut M, Lee KW, Shin JI. Seven recommendations to rescue the patients and reduce the mortality from COVID-19 infection: an immunological point of view. Autoimmun Rev. 2020;19(7):102570.

7. Joseph NT, Stanhope KK, Badell ML, Horton JP, Boulet SL, Jamieson DJ. Sociodemograhic predictors of SARS-CoV-2 infection in obstetric patients, Georgia. USA Emerg Infect Dis. 2020;26(11):2787-9. https://doi.org/10.3201/eid2611.203091.

8. Ceulemans M, Verbakel JY, Van Calsteren K, Eerdekens A, Allegaert K, Foulon V. SARS-CoV-2 infections and impact of the COVID-19 pandemic in pregnancy and breastfeeding: results from an observational study in primary care in Belgium. Int $\mathrm{J}$ Environ Res Public Health. 2020;17(18):E6766.

9. Afshar Y, Gaw SL, Flaherman VJ, Chambers BD, Krakow D, Berghella $\mathrm{V}$, et al. Clinical presentation of coronavirus disease 2019 (COVID-19) in pregnant and recently pregnant people. Obstet Gynecol. 2020. https://doi.org/10.1097/AOG. 0000000000004178.

10. Alay I, Yildiz S, Kaya C, Kart Yasar K, Altuntas Aydin O, Kumbasar Karaosmanoglu H, et al. The clinical findings and outcomes of symptomatic pregnant women diagnosed with or suspected of having coronavirus disease 2019 in a tertiary pandemic hospital in Istanbul, Turkey. J Obstet Gynaecol Res. 2020;46:2552-60. https://doi.org/10.1111/jog.14493.

11. Cosma S, Carosso AR, Cusato J, Borella F, Carosso M, Bovetti M, et al. COVID-19 and first trimester spontaneous abortion: a case-control study of 225 pregnant patients. Am J Obstet Gynecol. 2020 ;S0002-9378(20)31177-7. https://doi.org/10.1016/j.ajog. 2020.10 .005 .

12. Curi B, Sabre A, Benjamin I, Serventi L, Nuritdinova D. Coronavirus infection in a high risk obstetric population of the South Bronx. New York Am J Obstet Gynecol. 2020. https://doi. org/10.1016/j.ajogmf.2020.100203.

13. Di Mascio D, Sen C, Saccone G, Galindo A, Grünebaum A, Yoshimatsu J, et al. Risk factors associated with adverse fetal outcomes in pregnancies affected by Coronavirus disease 2019 (COVID-19): a secondary analysis of the WAPM study on COVID-19. J Perinat Med. 2020. https://doi.org/10.1515/jpm2020-0355.

14. Soffer MD, Shook LL, James K, Sawyer MR, Ciaranello A, Mahrouk R, et al. Protocol-driven intensive outpatient management of pregnant patients with symptomatic coronavirus disease 2019. Open Forum Infect Dis. 2020;7(11):ofaa524.

15. Dhuyvetter A, Cejtin HE, Adam M, Patel A. Coronvirus disease 2019 in pregnancy: the experience at an urban safety net hospital. J Community Health. 2020. https://doi.org/10.1007/s10900-02000940-7.
16. Liu D, Li L, Wu X, Zheng D, Wang J, Yang L, et al. Pregnancy and perinatal outcomes of women with coronavirus disease (COVID-19) pneumonia: a preliminary analysis. AJR Am J Roentgenol. 2020;18:1-6. https://doi.org/10.2214/AJR.20.23072.

17. Wei L, Gao X, Chen S, Zeng W, Wu J, Lin X, et al. Clinical characteristics and outcomes of childbearing-age women with coronavirus disease 2019 in Wuhan: a retrospective, single-center study. J Med Internet Res. 2020. https://doi.org/10.2196/19642.

18. la Cour Freiesleben N, Egerup P, Vauvert Römmelmayer Hviid K, Rosenbek Severinsen E, Kolte AM, Westergaard D, et al. SARSCoV-2 in first trimester pregnancy: a cohort study. Hum Reprod. 2020;36(1):40-7. https://doi.org/10.1093/humrep/deaa311.

19. Cheng B, Jiang T, Zhang L, Hu R, Tian J, Jiang Y, et al. Clinical characteristics of pregnant women with coronavirus disease 2019 in Wuhan, China. Open Forum Infect Dis. 2020;7(8):ofaa294.

20. Liao J, He X, Gong Q, Yang L, Zhou C, Li J. Analysis of vaginal delivery outcomes among pregnant women in Wuhan, China during the COVID-19 pandemic. Int J Gynaecol Obstet. 2020. https:// doi.org/10.1002/ijgo.13188.

21. Nayak AH, Kapote DS, Fonseca M, Chavan N, Mayekar R, Sarmalkar M, et al. Impact of the coronavirus infection in pregnancy: a preliminary study of 141 patients. J Obstet Gynaecol India. 2020;70(4):256-61.

22. Qiancheng X, Jian S, Lingling P, Lei H, Xiaogan J, Weihua L, et al. Coronavirus disease in 2019 in pregnancy. Int J Infect Dis. 2020;95:376-83.

23. Xu S, Shao F, Bao B, Ma X, Xu Z, You J, et al. Clinical manifestation and neonatal outcomes of pregnant patients with coronavirus disease 2019 pneumonia in Wuhan, China. Open Forum Infect Dis. 2020;7(7):ofaa283.

24. Yang H, Sun G, Tang F, Peng M, Gao Y, Peng J, et al. Clinical features and outcomes of pregnant women suspected of coronavirus disease 2019. J Inf Secur. 2020;S0163-4453(20)30212-7. https://doi.org/10.1016/j.jinf.2020.04.003.

25. Pirjani R, Hosseini R, Soori T, Rabiei M, Hosseini L, Abiri A, et al. Maternal and neonatal outcomes in COVID-19 infected pregnancies: a prospective cohort study. J Travel Med. 2020;27(7):taaa158. https://doi.org/10.1093/jtm/taaa158.

26. Fassett MJ, Lurvey LD, Yasumura L, Nguyen M, Colli JJ, Volodarskiy M, et al. Universal SARS-CoV-2 screening of women admitted for delivery in a large managed care organization. Am J Perinatol. 2020. https://doi.org/10.1055/s-0040-1714060.

27. Collin J, Byström E, Carnahan A, Ahrne M. Pregnant and postpartum women with SARS-CoV-2 infection in intensive care in Sweden. Acta Obstet Gynecol Scand. 2020. https://doi.org/10. 1111/aogs.13901.

28. Andrikopoulou M, Madden N, Wen T, Aubey JJ, Aziz A, Baptiste $\mathrm{CD}$, et al. Symptoms and critical illness among obstetric patients with coronavirus disease 2019 (COVID-19) infection. Obstet Gynecol. 2020;136(2):291-9.

29. Barbero P, Mugüerza L, Herraiz I, Garcia Burguillo A, San Juan R, Forcén L, et al. SARS-CoV-2 in pregnancy: characteristics and outcomes of hospitalized and non-hospitalized women due to COVID-19. J Matern Fetal Neonatal Med. 2020;20:1-7. https:/ doi.org/10.1080/14767058.2020.1793320.

30. Blitz MJ, Rochelson B, Minkoff H, Meirowitz N, Prasannan L, London $\mathrm{V}$, et al. Maternal mortality among women with coronavirus disease 2019 admitted to the intensive care unit. Am J Obstet Gynecol. 2020;S0002-9378(20)30636-0. https://doi.org/10.1016/ j.ajog.2020.06.020.

31. DeBolt CA, Bianco A, Limaye MA, Silverstein J, Penfield CA, Roman AS, et al. Pregnant women with severe or critical COVID19 have increased composite morbidity compared to non-pregnant matched controls. Am J Obstet Gynecol. 2020;S00029378(20)31312-0. https://doi.org/10.1016/j.ajog.2020.11.022. 
32. Diaz-Corvillón P, Mönckeberg M, Barros A, Illanes SE, Soldati A, Nien J-K, et al. Routine screening for SARS-CoV-2 in unselected pregnant women at delivery. PLoS One. 2020;15(9): e0239887.

33. Ellington S, Strid P, Tong VT, Woodworth K, Galang RR, Zambrano LD, et al. Characteristics of women of reproductive age with laboratory-confirmed SARS-CoV-2 infection by pregnancy status - United States, January 22-June 7, 2020. MMWR Morb Mortal Wkly. 2020;69(25):769-75.

34. Kayem G, Alessandrini V, Azria E, Blanc J, Bohec C, Bornes M, et al. A snapshot of the COVID-19 pandemic among pregnant women in France. J Gynecol Obstet Hum Reprod. 2020;49: 101826. https://doi.org/10.1016/j/jogoh.2020.101826.

35. Marin Gabriel MA, Reyne Vergeli M, Caserio Carbonero S, Sole L, Carrizosa Molina T, Rivero Calle I, et al. Maternal, perinatal and neonatal outcomes with COVID-19: a multicenter study of 242 pregnancies and their 248 infant newborns during their first month of life. Pediatr Infect Dis J. 2020. https://doi.org/10.1097/ INF0000000000002902.

36. Matar R, Alrahmani L, Monzer N, Debiane LG, Berbari E, Fares J, et al. Clinical presentation and outcomes of pregnant women with COVID-19: a systematic review and meta-analysis. Clin Infect Dis. 2020; ciaa828. https://doi.org/10.1093/cid/ciaa828.

37. Prabhu M, Cagino K, Matthews KC, Friedlander RL, Glynn SM, Kubiak JM, et al. Pregnancy and postpartum outcomes in a universally tested population for SARS-CoV-2 in New York City: a prospective cohort study. BJOG. 2020. https://doi.org/10.1111/ 1471-0528.16403.

38. Sahin D, Tanacan A, Erol SA, Anuk AT, Eyi EGY, Elif GYE, et al. A pandemic center's experience of managing pregnant women with COVID-19 infection in Turkey: a prospective cohort study. Int J Gynaecol Obstet. 2020. https://doi.org/10.1002/ijgo. 13318.

39. Sahin D, Tanacan A, Erol SA, Anuk AT, Yetiskin FDY, Keskin HL, et al. Updated experience of a tertiary pandemic center on 533 women with COVID-19 infection: a prospective cohort study from Turkey. Int J Gynaecol Obstet. 2020. https://doi.org/10. 1002/ijgo.13460.

40. Sattari M, Bashirian S, Masoumi SZ, Shayan A, Jenabi E, Ghelichkhani S, et al. Evalutating clinical course and risk factors of infection and demographic characteristics of pregnant women with COVID-19 in Hamadan province, west of Iran. J Res Health Sci. 2020;20(3):e00488.

41. Shmakov RG, Prikhodko A, Polushkina E, Shmakova E, Pyregov A, Bychenko V, et al. Clinical course of novel COVID-19 infection in pregnant women. J Matern Fetal Neonatal Med. 2020;29: 1-7. https://doi.org/10.1080/14767058.2020.1850683.

42. Tug N, Yassa M, Köle E, Sakin Ö, Çakir Köle M, Karateke A, et al. Pregnancy worsens the morbidity of COVID-19 and this effect becomes more prominent as pregnancy advances. Turk $\mathrm{J}$ Obstet Gynecol. 2020;17(3):149-54.

43. Wu X, Sun R, Chen J, Xie Y, Zhang S, Wang X. Radiological findings and clinical characteristics of pregnant women with COVID-19 pneumonia. Int J Gynaecol Obstet. 2020;150(1):5863.

44. Zambrano LD, Ellington S, Strid P, Galang RR, Oduyebo T, Tong VT, et al. Update: characteristics of symptomatic women of reproductive age with laboratory-confirmed SARS-CoV-2 infection by pregnancy status - United States, January 22-October 3, 2020. MMWR Morb Mortal Wkly Rep. 2020;69(44):1641-7.

45. Wong SF, Chow KM, Leung TN, Ng WF, Ng TK, et al. Pregnancy and perinatal outcomes of women with severe acute respiratory syndrome. Am J Obstet Gynecol. 2004;191(1):292-7.

46. Chen L, Li Q, Zheng D, Jiang H, Wei Y, Zou L, et al. Clinical characteristics of pregnant women with COVID-19 in Wuhan,
China. N Engl J Med. 2020;382(25):e100. https://doi.org/10. 1056/NEJMc2009226.

47. Barroso Dos Reis HL, Tosato Boldrini NA, Jacomele Caldas JV, Calazans da Paz AP, Loyola Prest Ferrugini C, Espinosa Miranda A. Severe coronavirus infection in pregnancy: challenging cases report. Rev Inst Med Trop Sao Paulo. 2020;62:e49. https://doi. org/10.1590/s1678-9946202062049.

48. Cimolai N. Features of enteric disease from human coronaviruses: implications for COVID-19. J Med Virol. 2020. https://doi.org/10. 1002/jmv.26066.

49. Ahmed I, Eltaweel N, Antoun L, Rehal A. Severe pre-eclampsia complicated by acute fatty liver disease of pregnancy, HELLP syndrome and acute kidney injury following SARS-CoV-2 infection. BMJ Case Rep. 2020;13(8):e237521.

50. Bandara S, Ruwanpathirana A, Nagodawithana D, Alwis S. Hypertensive crisis in pregnancy with COVID-19: confirmed with RT-PCR for nasopharyngeal swab. Case Rep Obstet Gynecol. 2020;2020:8868952. https://doi.org/10.1155/2020/8868952.

51. Chen S, Liao E, Cao D, Gao Y, Sun G, Shao Y. Clinical analysis of pregnant women with 2019 novel coronavirus pneumonia. J Med Virol. 2020. https://doi.org/10.1002/jmv.25789.

52. Correia CR, Marçal M, Vieira F, Santos E, Novais C, Maria AT, et al. Congenital SARS-CoV-2 infection in a neonate with severe acute respiratory syndrome. Pediatr Infect Dis J. 2020. https://doi. org/10.1097/INF.0000000000002941.

53. Gidlöf S, Savchenko J, Brune T, Josefsson H. COVID-19 in pregnancy with comorbidities: more liberal testing strategy is needed. Acta Obstet Gynecol Scand. 2020;99(7):948-9.

54. Hosier H, Farhadian SF, Morotti RA, Deshmukh U, Lu-Culligan A, Campbell KH, et al. SARS-CoV-2 infection of the placenta. J Clin Invest. 2020 ;139569. https://doi.org/10.1172/JCI139569.

55. Huang $\mathrm{W}$, Zhao Z, He Z, Liu S, Wu Q, Zhang X, et al. Unfavorable outcomes in pregnant patients with COVID-19. J Inf Secur. 2020;81(2):e999-1001.

56. Jenabi E, Bashirian S, Khazaei S, Masoumi SZ, Ghelichkhani S, Goodarzi F, et al. Pregnancy outcomes among symptomatic and asymptomatic women infected with COVID-19 in the west of Iran: a case-control study. J Matern Fetal Neonatal Med. 2020;13. https://doi.org/10.1080/14767058.2020.1861599.

57. Joudi N, Henkel A, Lock WS, Lyell D. Pre-eclampsia treatment in SARS-CoV-2. Am J Obstet Gynecol MFM. 2020;2(3):100146. https://doi.org/10.1016/j.ajogmf.2020.100146.

58. Majachani N, Francois JLM, Fernando AK, Zuberi J. A case of a newborn baby girl infected with SARS-CoV-2 due to transplacental viral transmission. Am J Case Rep. 2020;21:e925766-1-5. https://doi.org/10.12659/AJCR.925766.

59. Sentilhes L, De Marcillac F, Jouffrieau C, Kuhn P, Thuet V, Hansmann Y, et al. Coronavirus disease 2019 in pregnancy was associated with maternal morbidity and preterm birth. Am J Obstet Gynecol. 2020;S0002-9378(20)30639-6. https://doi.org/10.1016/ j.ajog.2020.06.022.

60. Gulersen M, Prasannan L, Tam Tam H, Metz CN, Rochelson B, Meirowitz N, et al. Histopathological evaluation of placentas after diagnosis of maternal SARS-CoV-2 infection. Am J Obstet Gynecol MFM. 2020;2(4, Supplement):100211. https://doi.org/ 10.1016/j/ajogmf.2020.100211.

61. Adhikari EH, Moreno W, Zofkie AC, MacDonald L, McIntire DD, Collins RRJ, et al. Pregnancy outcomes among women with and without severe acute respiratory syndrome coronavirus 2 infection. JAMA Netw Open. 2020;3(11):e2029256.

62. Federici L, Picone O, Dreyfuss D, Sibiude J. Successful continuation of pregnancy in a patient with COVID-19-related ARDS. BMJ Case Rep. 2020;13(8):e237511.

63. Kadir RA, Kobayashi T, Iba T, Erez O, Thachil J, Kazi S, et al. COVID-19 coagulopathy in pregnancy: critical review, preliminary recommendations and ISTH registry - communication from 
the ISTH SSC for Women's Health. J Thromb Haemost. 2020. https://doi.org/10.1111/jth.15072.

64. Vadlamudi G, Hong L, Keerthy M. Evans syndrome associated with pregnancy and COVID-19 infection. Case Rep Obstet Gynecol. 2020;2020:8862545.

65. Hong L, Smith N, Keerthy M, Lee-Griffith M, Garcia R, Shaman $\mathrm{M}$, et al. Severe COVID-19 infection in pregnancy requiring intubation without preterm delivery: a case report. Case Rep Womens Health. 2020;e00217:27.

66. Algeri P, Stagnati V, Donata Spazzini M, Bellan C, Montanelli A, et al. Considerations on COVID-19 pregnancy: a case series during outbreak in Bergamo Province, North Italy. J Matern Fetal Neonatal Med. 2020 ;1-4. https://doi.org/10.1080/14767058.

67. Alsayyed F, Hastings V, Lederman S. Expectant management of a critically ill pregnant patient with COVID-19 with good maternal and neonatal outcomes. Case Rep Obstet Gynecol. 2020;2020: 8891787. https://doi.org/10.1155/2020/8891787.

68. Antoun L, El Taweei N, Ahmed I, Patni S, Honest H. Maternal COVID-19 infection, clinical characteristics, pregnancy, and neonatal outcome: a prospective cohort study. Eur J Obstet Gynecol Reprod Biol. 2020; S0301-2115(20)30448-6. https://doi.org/10. 1016/j.ejogrb.2020.07.008.

69. Blauvelt CA, Chiu C, Donovan AL, Prahl M, Shimotake TK, George RB, et al. Acute respiratory distress syndrome in a preterm pregnant patient with coronavirus disease 2019 (COVID-19). Obstet Gynecol. 2020;136(1):46-51.

70. Cooke WR, Billett A, Gleeson S, Jacques A, Place K, Siddall J, et al. SARS-CoV-2 infection in very preterm pregnancy: experiences from two cases. Eur J Obstet Gynecol Reprod Biol. 2020;250:259-60.

71. Delahoy MJ, Whitaker M, O'Halloran A, Chai SJ, Kirley PD, Alden N, et al. Characteristics and maternal and birth outcomes of hospitalized pregnant women with laboratory-confirmed COVID-19 - COVID-NET, 13 states, March 1-August 22, 2020. MMWR Morb Mortal Wkly Rep. 2020;69(38):1347-54.

72. Di Mascio D, WAPM Working Group on COVD-19. Maternal and perinatal outcomes of pregnant women with SARS-CoV-2 infection. Ultrasound Obstet Gynecol. 2020. https://doi.org/10. 1002/uog.23107.

73. Edlow AG, Li JZ, Collier A-RY, Atyeo C, James KE, Boatin AA, et al. Assessment of maternal and neonatal SARS-CoV-2 viral load, transplacental antibody transfer, and placental pathology in pregnancies during the COVID-19 pandemic. JAMA Netw Open. 2020;3(12):e2030455.

74. Ferrazzi EM, Frigerio L, Cetin I, Vergani P, Spinillo A, Prefumo F, et al. COVID-19 obstetrics task force, Lombardy, Italy: executive management summary and short report of outcome. Int J Gynaecol Obstet. 2020;149(3):377-8.

75. Ferrazzi EM, Frigerio L, Savasi V, Vergani P, Prefumo F, Barresi $\mathrm{S}$, et al. Vaginal delivery in SARS-CoV-2 infected pregnant women in Northern Italy: a retrospective analysis. BJOG. 2020:27. https://doi.org/10.1111/1471-0528.16278.

76. Hantoushzadeh S, Shamshirsaz AA, Aleyasin A, Seferovic MD, Kazemi Aski S, Arian SE, et al. Maternal death due to COVID-19. Am J Obstet Gynecol. 2020;223(1):109.e1-6.

77. Khoury R, Bernstein PS, Debolt C, Stone J, Sutton DM, Simpson LL, et al. Characteristics and outcomes of 241 births to women with severe acute respiratory syndrome coronavirus 2 (SARS$\mathrm{CoV}-2)$ infection at five New York City medical centers. Obstet Gynecol. 2020.https://doi.org/10.1097/AOG. 0000000000004025 .

78. Li J, Wang Y, Zeng Y, Song T, Pan X, Jia M, et al. Critically ill pregnant patient with COVID-19 and neonatal death within two hours of birth. Int J Gynaecol Obstet. 2020;150(1):126-8.

79. Lokken EM, Walker CL, Delaney S, Kachikis A, Kretzer N, Erickson A, et al. Clinical characteristics of 46 pregnant women with a SARS-CoV-2 infection in Washington State. Am J Obstet Gynecol. 2020;S0002-9378(20)30558-5. https://doi.org/10.1016/ j.ajog.2020.05.031.

80. Lumbreras-Marquez MI, Campos-Zamora M, Lizaola-Diaz de Leon H, Farber MK. Maternal mortality from COVID-19 in Mexico. Int J Gynaecol Obstet. 2020;150(2):266-7.

81. Panagiotakopoulos L, Myers TR, Gee J, Lipkind HS, Kharbanda EO, Ryan DS, et al. SARS-CoV-2 infection among hospitalized pregnant women: reasons for admission and pregnancy characteristics - eight U.S. health care centers, March 1-May 30, 2020. MMWR Morb Mortal Wkly Rep. 2020;69(38):1355-9.

82. Pereira A, Cruz-Melguizo S, Adrien M, Fuentes L, Marin E, Perez-Medina T. Clinical course of coronavirus disease - 2019 (COVID-19) in pregnancy. Acta Obstet Gynecol Scand. 2020. https://doi.org/10.1111/aogs.13821.

83. Pierce-Williams RAM, Burd J, Felder L, Khoury R, Bernstein PS, Avila K, et al. Clinical course of severe and critical COVID-19 in hospitalized pregnancies: a US cohort study. Am J Obstet Gynecol MFM. 2020;2(3):100134. https://doi.org/10.1016/j.ajogmf.2020. 100134.

84. Pourdowlat G, Mikaeilvand A, Eftekhariyazdi M, Nematshahi M, Ebrahimi M, Kazemzadeh A. Prone-position ventilation in a pregnant woman with severe COVID-19 infection associated with acute respiratory distress syndrome. Tanaffos. 2020;19:152-5.

85. Safaee Fakhr B, Wiegand SB, Pinciroli R, Gianni S, Morais CCA, Ikeda $\mathrm{T}$, et al. High concentrations of nitric oxide inhalation therapy in pregnant patients with severe coronavirus disease 2019 (COVID-19). Obstet Gynecol. 2020. https://doi.org/10.1097/ AOG.0000000000004128.

86. San-Juan R, Barbero P, Fernández-Ruiz M, López-Medrano F, Lizasoáin M, Hernández-Jiménez $\mathrm{P}$, et al. Incidence and clinical profiles of COVID-19 pneumonia in pregnant women: a singlecentre cohort study from Spain. EClin Med. 2020;23:100407.

87. Savasi VM, Parisi F, Patanè L, Ferrazzi E, Frigerio L, Pellegrino A, et al. Clinical findings and disease severity in hospitalized pregnant women with coronavirus disease 2019 (COVID-19). Obstet Gynecol. 2020. https://doi.org/10.1097/AOG. 0000000000003979 .

88. Takemoto MLS, Menezes MO, Andreucci CB, Nakamura-Pereira $\mathrm{M}$, et al. The tragedy of COVID-19 in Brazil: 124 maternal deaths and counting. Int J Gynecol Obstet. 2020. https://doi.org/10.1002/ ijgo.13300.

89. Vivanti A, Mattern J, Vauloup-Fellous C, Jani J, Rigonnot L, El Hachem L, et al. Retrospective description of pregnant women infected with severe acute respiratory syndrome coronavirus 2 , France. Emerg Infect Dis. 2020;26(9):2069-76. https://doi.org/ 10.3201/eid2609.202144.

90. Yan J, Guo J, Fan C, Juan J, Yu X, Li J, et al. Coronavirus disease 2019 in pregnant women: a report based on 116 cases. Am J Obstet Gynecol. 2020;S0002-9378(20)30462-2. https://doi.org/ 10.1016/j.ajog.2020.04.014

91. Yu Y, Fan C, Bian J, Shen Y. Severe COVID-19 in a pregnant patient admitted to hospital in Wuhan. Int J Gynaecol Obstet. 2020;150(2):262-3.

92. Gulersen M, Staszewski C, Grayver E, Tam Tam H, Gottesman E, Isseroff D, et al. Coronavirus disease 2019 (COVID-19)-related multisystem inflammatory syndrome in a pregnant woman. Obstet Gynecol. 2020.https://doi.org/10.1097/AOG. 0000000000004256 .

93. Ahmed I, Azhar A, Eltaweel N, Tan BK. First COVID-19 maternal mortality in the UK associated with thrombotic complications. Br J Haematol. 2020;190(1):e37-8.

94. Knight M, Bunch K, Vousden N, Morris E, Simpson N, Gale C, et al. Characteristics and outcomes of pregnant women admitted to hospital with confirmed SARS-CoV-2 infection in UK: national 
population based cohort study. BMJ. 2020;369:m2107. https:// doi.org/10.1136/bmj.m2107.

95. Schwartz DA, Mohagheghi P, Beigi B, Zafaranloo N, Moshfegh F, Yazdani A. Spectrum of neonatal COVID-19 in Iran: 19 infants with SARS-CoV-2 perinatal infections with varying test results, clinical findings and outcomes. J Matern Fetal Neonatal Med 2020;1-10. doi: https://doi.org/10.1080/14767058.2020.1797672

96. Takemoto MLS, Menezes MO, Andreucci CB, Knobel R, Sousa LAR, Katz L, et al. Maternal mortality and COVID-19. J Matern Fetal Neonatal Med 2020;1-7. doi: https://doi.org/10.1080/ 14767058.2020.1786056

97. Vallejo V, Ilagan JG. A postpartum death due to coronavirus disease in 2019 (COVID-19) in the United States. Obstet Gynecol. 2020;136(1):52-5.

98. Zamaniyan M, Ebadi A, Aghajanpoor S, Rahmani Z, Haghshenas M, Azizi S. Preterm delivery, maternal death, and vertical transmission in a pregnant woman with COVID-19 infection. Prenat Diagn. 2020. https://doi.org/10.1002/pd.5713.

99. Erol SA, Tanacan A, Anuk AT, Tokalioglu EO, Biriken D, Keskin $\mathrm{HL}$, et al. Evaluation of maternal serum afamin and vitamin $\mathrm{E}$ levels in pregnant women with COVID-19 and its association with composite adverse perinatal outcomes. J Med Virol. 2020. https:// doi.org/10.1002/jmv.26725.

100. Chen R, Zhang Y, Huang L, Cheng B-H, Xia Z-Y, Meng Q-T. Safety and efficacy of different anesthetic regimens for parturients with COVID-19 undergoing Cesarean delivery: a case series of 17 patients. Can J Anaesth. 2020;67(6):655-63.

101. Gulersen M, Blitz MJ, Rochelson B, Nimaroff M, Shan W, Bornstein E. Clinical implications of SARS-CoV-2 infection in the viable preterm period. Am J Perinatol. 2020. https://doi.org/ 10.1055/s-0040-1713851.

102. Khan S, Jun L, Nawsherwan, Siddique R, Li Y, Han G, et al. Association of COVID-19 with pregnancy outcomes in healthcare workers and general women. Clin Microbiol Infect. 2020;26(6):788-90.

103. Li Y, Zhao R, Zheng S, Chen X, Wang J, Sheng X, et al. Lack of vertical transmission of severe acute respiratory syndrome coronavirus 2, China. Emerg Infect Dis. 2020;26(6):1335-6.

104. London V, McLaren R, Atallah F, Cepeda C, McCalla S, Fisher N, et al. The relationship between status at presentation and outcomes among pregnant women with COVID-19. Am J Perinatol. 2020. https://doi.org/10.1055/s-0040-1712164.

105. Moreno SC, To J, Chun H, Ngai IM. Vertical transmission of COVID-19 to the neonate. Infect Dis Obstet Gynecol. 2020;2020:8460672. https://doi.org/10.1155/2020/8460672.

106. Ogamba I, Kliss A, Rainville N, Chuang L, Panarelli E, Petrini J, et al. Initial review of pregnancy and neonatal outcomes of pregnant women with COVID-19 infection. J Perinat Med. 2020. https://doi.org/10.1515/jpm-2020-0446.

107. Villalain C, Herraiz I, Luczkowiak J, Pérez-Rivilla A, Folgueira MD, Mejia I, et al. Seroprevalence analysis of SARS-CoV-2 in pregnant women along the first pandemic outbreak and perinatal outcome. PLoS One. 2020;15:e243029.

108. Woodworth KR, O'Malley Olsen E, Neelam V, Lewis EL, Galang $\mathrm{RR}$, Oduyebo T, et al. Birth and infant outcomes following laboratory-confirmed SARS-CoV-2 infection in pregnancy SET-NET, 16 jurisdictions, March 29-October 14, 2020. MMWR Morb Mortal Wkly Rep. 2020;69(44):1635-40.

109. Yang R, Mei H, Zheng T, Fu Q, Zhang Y, Buka S, et al. Pregnant women with COVID-19 and risk of adverse birth outcomes and maternal-fetal vertical transmission: a population-based cohort study in Wuhan, China. BMC Med. 2020;18(1):330.

110. Zeng Y, Lin L, Yan Q, Wei W, Yang BX, Huang R, et al. Update on clinical outcomes of women with COVID-19 during pregnancy. Int J Gynaecol Obstet. 2020;150(2):264-6.
111. Hu X, Gao J, Luo X, Feng L, Liu W, Chen J, et al. Severe acute respiratory syndrome coronavirus 2 (SARS-CoV-2) vertical transmission in neonates born to mothers with coronavirus disease 2019 (COVID-19) pneumonia. Obstet Gynecol. 2020;136(1): 65-7.

112. Hu X, Gao J, Wei Y, Chen H, Sun X, Chen J, et al. Managing preterm infants born to COVID-19 mothers: evidence from a retrospective cohort study in Wuhan, China. Neonatology. 2020;117(5):592-8. 1-7. https://doi.org/10.1159/000509141.

113. Qadri F, Mariona F. Pregnancy affected by SARS-CoV-2 infection: a flash report from Michigan. J Matern Fetal Neonatal Med 2020;1-3. doi:https://doi.org/10.1080/14767058.2020.1765334

114. Wu C, Yang W, Wu X, Zhang T, Zhao Y, Ren W, et al. Clinical manifestation and laboratory characteristics of SARS-CoV-2 infection in pregnant women. Virol Sin. 2020;35(3):305-10.

115. Sun G, Zhang Y, Liao Q, Cheng Y. Blood test results of pregnant COVID-19 patients: an updated case-control study. Front Cell Infect Microbiol. 2020;10:560899. https://doi.org/10.3389/fcimb. 2020.560899.

116. Wu Y-T, Liu J, Xu J-J, Chen Y-F, Yang W, Chen Y, et al. Neonatal outcome in 29 pregnant women with COVID-19: a retrospective study in Wuhan, China. PLoS Med. 2020;17(7): e1003195.

117. Ali A, Rashid Z, Zhou J, Yousef MZ, Galani S, Ashraf A, et al. Evaluating antibody response pattern in asymptomatic virus infected pregnant females: human well-being study. J King Saud Univ Sci. 2020;33(1):101255. https://doi.org/10.1016/j.jksus. 2020.101255.

118. Biasucci G, Cannalire G, Raymond A, Capra ME, Benenati B, Vadacca G, et al. Safe perinatal management of neonates born to SARS-CoV-2 positive mothers at the epicenter of the Italian epidemic. Front Pediatr. 2020;8:565522. https://doi.org/10.3389/ fped.2020.565522.

119. Breslin N, Baptiste C, Gyamfi-Bannerman C, Miller R, Martinez $\mathrm{R}$, Bernstein K, et al. COVID-19 infection among asymptomatic and symptomatic pregnant women: two weeks of confirmed presentations to an affiliated pair of New York City hospitals. Am J Obstet Gynecol MFM. 2020;2(2):100118. https://doi.org/10. 1016/j.ajogmf.2020.100118.

120. Chen Y, Bai J. Maternal and infant outcomes of full-term pregnancy combined with COVID-19 in Wuhan, China: retrospective case series. Arch Gynecol Obstet. 2020. https://doi.org/10.1007/ s00404-020-05573-8.

121. Chen S, Huang B, Luo DJ, Li X, Yang F, Zhao Y, et al. Pregnancy with new coronavirus infection: clinical characteristics and placental pathological analysis of three cases. Zhonghua Bing Li Xue Za Zhi. 2020;49(5):418-23.

122. Chen Y, Peng H, Wang L, Zhao Y, Zeng L, Gao H, et al. Infants born to mothers with a new coronavirus (COVID-19). Front Pediatr. 2020;8:104. https://doi.org/10.3389/fped.2020.00104.

123. Dória $M$, Peixinho $C$, Laranjo $M$, Varejão $A M$, Tiago SP. COVID-19 during pregnancy: a case series from an universally tested population from the north of Portugal. Eur J Obstet Gynecol Reprod Biol. 2020. https://doi.org/10.1016/j.ejogrb.2020.05.029.

124. Douedi S, Albayati A, Alfraji N, Mazahir U, Costanzo E. Successful maternal and fetal outcomes in COVID-19 pregnant women: an institutional approach. Am J Case Rep. 2020;21: e925513. https://doi.org/10.12659/AJCR.925513.

125. Hecht JL, Quade B, Deshpande V, Mino-Kenudson M, Ting TT, Desai N, et al. SARS-CoV-2 can infect the placenta and is not associated with specific placental histopathology: a series of 19 placentas from COVID-19-positive mothers. Mod Pathol 2020 ;112. doi: https://doi.org/10.1038/s41379-020-0639-4

126. Liu W, Cheng H, Wang J, Ding L, Zhou Z, Liu S, et al. Clinical analysis of neonates born to mothers with or without COVID-19: a retrospective analysis of 48 cases from two neonatal intensive care 
units in Hubei Province. Am J Perinatol. 2020. https://doi.org/10. 1055/s-0040-1716505.

127. Ronchi A, Pietrasanta C, Zavattoni M, Schena F, Sinelli MT, et al. Evaluation of rooming-in practice for neonates born to mothers with severe acute respiratory syndrome coronavirus 2 infection in Italy. JAMA Pediatr. 2020. https://doi.org/10.1091/ jamapediatrics.2020.5086.

128. Zhang L, Dong L, Ming L, Wei M, Li J, Hu R, et al. Severe acute respiratory syndrome coronavirus 2 (SARS-CoV-2) infection during late pregnancy: a report of 18 patients from Wuhan, China. BMC Pregnancy Childbirth. 2020;20(1):394.

129. Zhang L, Jiang Y, Wei M, Cheng BH, Zhou XC, Li J, et al. Analysis of the pregnancy outcomes in pregnant women with COVID-19 in Hubei province. Zhonghua Fu Chan Ke Za Zhi. 2020;55(3):166-71.

130. Khan S, Peng L, Siddique R, Nabi G. Nawsherwan, Xue M, et al. Impact of COVID-19 infection on pregnancy outcomes and the risk of maternal-to-neonatal intrapartum transmission of COVID19 during natural birth. Int J Gynaecol Obstet. 2020;41(6):748-50.

131. Ceulemans M, Hompes T, Foulon V. Mental health status of pregnant and breastfeeding women during the COVID-19 pandemic: a call for action. Int J Gynecol Obstet. 2020. https://doi.org/10.1002/ ijgo.13295.

132. Molgora S, Accordini M. Motherhood in the time of coronavirus: the impact of the pandemic emergency on expectant and postpartum women's psychological well-being. Front Psychol. 2020;11: 567155. https://doi.org/10.3389/fpsyg.2020.567155.

133. Parra-Saavedra M, Villa-Villa I, Pérez-Olivo J, Guzman-Polania L, Galvis-Centurion P, Cumplido-Romero Á, et al. Attitudes and collateral psychological effects of COVID-19 in pregnant women in Colombia. Int J Gynaecol Obstet. 2020. https://doi.org/10.1002/ ijgo.13348.

134. Patabendige M, Gamage MM, Weerasinghe M, Jayawardane A. Psychological impact of the COVID-19 pandemic among pregnant women in Sri Lanka. Int J Gynecol Obstet. 2020. https://doi. org/10.1002/ijgo.13335.

135. La Scola B, Le Bideau M, Adreani J, Huang VT, Grimaldier C, Colson P, et al. Viral RNA load as determined by cell culture as a management tool for discharge of SARS-CoV-2 patients from infectious disease wards. Eur J Clin Microbiol Infect Dis. 2020;39(6):1059-61.

136. Bertino E, Moro GE, De Renzi G, Viberti G, Cavallo R, Coscia A, et al. Detection of SARS-CoV-2 in milk from COVID-19 positive mothers and follow-up of their infants. Front Pediatr. 2020;8: 597699. https://doi.org/10.3389/fped.2020.597699.

137. Kelly JC, Dombrowski M, O'Neil-Callahan M, Kernberg AS, Frolova AI, Stout MJ. False-negative COVID-19 testing: considerations in obstetrical care. Am J Obstet Gynecol MFM. 2020;2(3):100130. https://doi.org/10.1016/j.ajogmf.2020. 100130.

138. Dong L, Tian J, He S, Zhu C, Wang J, Liu C, et al. Possible vertical transmission of SARS-CoV-2 from an infected mother to her newborn. JAMA. 2020;323(18):1846-8.

139. Savirón-Cornudella R, Villalba A, Zapardiel J, Andeyro-Garcia M, Esteban LM, Pérez-López FR. Severe acute respiratory syndrome coronavirus 2 (SARS-CoV-2) universal screening in gravids during labor and delivery. Eur J Obstet Gynecol Reprod Biol. 2020;256:400-4.

140. Zeng H, Xu C, Fan J, Tang Y, Deng Q, Zhang W, et al. Antibodies in infants born to mothers with COVID-19 pneumonia. JAMA. 2020;323(18):1848-9.

141. Zhang H-J, Su Y-Y, Xu S-L, Chen G-Q, Li C-C, Jiang R-J, et al. Asymptomatic and symptomatic SARS-CoV-2 infections in close contacts of COVID-19 patients: a seroepidemiological study. Clin Infect Dis. 2020; ciaa771. https://doi.org/10.1093/cid/ciaa771.
142. Carosso A, Cosma S, Borella F, Marozio L, Coscia A, Ghisetti V, et al. Pre-labor anorectal swab for SARS-CoV-2 in COVID-19 pregnant patients: is it time to think about it? Eur J Obstet Gynecol Reprod Biol. 2020;249:98-9.

143. Cavaliere AF, Marchi L, Aquilini D, Brunelli T, Vassari PL. Passive immunity in newborn from SARS-CoV-2 infected mother. J Med Virol. 2020. https://doi.org/10.1002/jmv.26609.

144. Peng J, Li R, Yin H, Tang F, Xie H, Li M, et al. A case report of a pregnant woman infected with coronavirus disease 2019 pneumonia. Medicine. 2020;99(30):e21335.

145. Sileo FG, Tramontano AL, Leone C, Meacci M, Gennari W, Ternelli G, et al. Pregnant woman infected by coronavirus disease (COVID-19) and calcifications of the fetal bowel and gallbladder: a case report. Minerva Ginecol. 2020. https://doi.org/10.23736/ S0026-4784.20.04717-6.

146. Gupta A, Malhotra Y, Patil U, Muradas AR, Lee WT, Krammer F, et al. In utero vertical transmission of coronavirus disease 2019 in a severely ill 29-week infant. AJP Rep. 2020;10(3):e270-4.

147. Anderson JD, Thomas EE, Cimolai N. Chapter 6. Infections and the conceptus. In: Dimmick JE, Kalousek DK, editors. Developmental Pathology of the Embryo and Fetus. Philadelphia: J. B. Lippincott Company; 1992. p. 143-98.

148. De Ioris MA, Scarselli A, Ciofi Degli Atti ML, Ravà L, Smarrazzo A, Concato C, et al. Dynamic viral SARS-CoV-2 RNA shedding in children: preliminary data and clinical consideration from a Italian Regional Center. J Pediatric Infect Dis Soc. 2020; piaa065. https://doi.org/10.1093/jpids/piaa065.

149. Demirjian A, Singh C, Tebruegge M, Herbert R, Draz N, Mirfenderesky $\mathrm{M}$, et al. Probable vertical transmission of SARS-CoV-2 infection. Pediatr Infect Dis J. 2020. https://doi. org/10.1097/INF.0000000000002821.

150. Eberhardt KA, Meyer-Schwickerath C, Heger E, Knops E, Lehmann C, Rybniker J, et al. RNAemia corresponds to disease severity and antibody response in hospitalized COVID-19 patients. Viruses. 2020;12(9):E1045.

151. Huang J-T, Ran R-X, Lv Z-H, Feng L-N, Ran C-Y, Tong Y-Q, et al. Chronological changes of viral shedding in adult inpatients with COVID-19 in Wuhan, China. Clin Infect Dis. 2020; ciaa631. https://doi.org/10.1093/cid/ciaa631.

152. Kirtsman M, Diambomba Y, Poutanen SM, Malinowski AK, Vlachodimitropoulou E, Parks WT, et al. Probable congenital SARS-CoV-2 infection in a neonate born to a woman with active SARS-CoV-2 infection. CMAJ. 2020;192(24):E647-50.

153. Ling Y, Xu S-B, Lin Y-X, Tian D, Zhu Z-Q, Dai F-H, et al. Persistence and clearance of viral RNA in 2019 novel coronavirus disease rehabilitation patients. Chin Med J. 2020;133(9):1039-43.

154. Wang W, Xu Y, Gao R, Lu R, Wu G, et al. Detection of SARSCoV-2 in different types of clinical specimens. JAMA. 2020;323(18): 1843-4.

155. Wölfel R, Corman VM, Guggemos W, Seilmaier M, Zange S, Müller MA, et al. Virological assessment of hospitalized patients with COVID-2019. Nature. 2020. https://doi.org/10.1038/s41586020-2196-x.

156. Xie C, Jiang L, Huang G, Pu H, Gong B, Lin H, et al. Comparison of different samples for 2019 novel coronavirus detection by nucleic amplification tests. Int J Infect Dis 2020

157. Young BE, Ong SWX, Kalimuddin S, Low JG, Tan SY, Loh J, et al. Epidemiologic features and clinical course of patients with SARS-CoV-2 in Singapore. JAMA. 2020. https://doi.org/10. 0110/jama.2020.3204.

158. Zhang W, Du RH, Li B, Zheng XS, Yang XL, Chen D, et al. Molecular and serological investigation of 2019-nCoV infected patients: implications of multiple shedding route. Emerg Microbes Infect. 2020;9(1):386-9. 
159. Zhou J, Li C, Liu X, Chiu MC, Zhao X, Wang D, et al. Infection of bat and human intestinal organoids by SARS-CoV-2. Nat Med. 2020. https://doi.org/10.1038/s41591-020-0912-6.

160. Zhang Y, Chen C, Zhu S, Shu C, Wang D, Song J, et al. Isolation of 2019-nCoV from a stool specimen of a laboratory confirmed case of the coronavirus disease 2019 (COVID-19). China CDC Wkly. 2020;2(8):123-4.

161. Gagneur A, Dirson E, Audebert S, Vallet S, Legrand-Quillien MC, Laurent Y, et al. Materno-fetal transmission of human coronaviruses: a prospective pilot study. Eur J Clin Microbiol Infect Dis. 2008;27(9):863-6.

162. Fan C, Lei D, Fang C, Li C, Wang M, Liu Y, et al. Perinatal transmission of COVID-19 associated SARS-CoV-2: should we worry? Clin Infect Dis 2020; ciaa226. https://doi.org/10.1093/cid/ ciaa226.

163. Gao X, Wang S, Zeng W, Chen S, Wu J, Lin W, et al. Clinical and immunological features among COVID-19 affected mother-infant pairs: antibodies to SARS-CoV-2 detected in breast milk. New Microbes New Infect. 2020;37:100752. https://doi.org/10.1016/j. nmni.2020.100752.

164. Grimminck K, Santegoets LAM, Siemens FC, Leendert P, Fraaij A, Reiss IKM, et al. No evidence of vertical transmission of SARS-CoV-2 after induction of labour in an immune-suppressed SARS-CoV-2-positive patient. BMJ Case Rep. 2020;13(6): e235581.

165. Hinojosa-Velasco A, Bobadilla-Montes de Oca PV, Garcia-Sosa LE, Mendoza-Durán JG, Pérez-Méndez MJ, Dávila-González E, et al. A case report of newborn infant with severe COVID-19 in Mexico: detection of SARS-CoV-2 in human breast milk and stool. Int J Infect Dis. 2020 ;S1201-9712(20)30684-6. https:// doi.org/10.1016/j.ijid.2020.08.055.

166. Peng Z, Wang J, Mo Y, Duan W, Xiang G, Yi M, et al. Unlikely SARS-CoV-2 vertical transmission from mother to child: a case report. J Infect Public Health. 2020;13(5):818-20.

167. Tam PCK, Ly KM, Kernich ML, Spurrier N, Lawrence D, Gordon DL, et al. Detectable severe acute respiratory syndrome coronavirus 2 (SARS-CoV-2) in human breast milk of a mildly symptomatic patient with coronavirus disease 2019 (COVID-19). Clin Infect Dis. 2020; ciaa673. https://doi.org/10.1093/cid/ciaa673.

168. Wu Y, Liu C, Dong L, Zhang C, Chen Y, Liu J, et al. Coronavirus disease 2019 among pregnant Chinese women: case series data on the safety of vaginal birth and breastfeeding. BJOG. 2020. https:// doi.org/10.1111/1471-0528.16276.

169. Xiong X, Wei H, Zhang Z, Chang J, Ma X, Gao X, et al. Vaginal delivery report of a healthy neonate born to a convalescent mother with COVID-19. J Med Virol. 2020. https://doi.org/10.1002/jmv. 25857.

170. Sun J, Zhu A, Li H, Zheng K, Zhuang Z, Chen Z, et al. Isolation of infectious SARS-CoV-2 from urine of a COVID-19 patient. Emerg Microbes Infect. 2020;9(1):991-3.

171. Qiu L, Liu X, Xiao M, Xie J, Cao W, Liu Z, et al. SARS-CoV-2 is not detectable in the vaginal fluid of women with severe COVID19 infection. Clin Infect Dis. 2020;71(15):813-7.

172. Cimolai N. Environmental and decontamination issues for human coronaviruses and their potential surrogates. J Med Virol. 2020. https://doi.org/10.1002/jmv.26170.

173. Ornaghi S, Callegari C, Milazzo R, La Milia L, Brunetti F, Lubrano $\mathrm{C}$, et al. Performance of an extended triage questionnaire to detect suspected cases of severe acute respiratory syndrome coronavirus 2 (SARS-CoV-2) infection in obstetric patients: experience from two large teaching hospitals in Lombardy, Northern Italy. PLoS One. 2020;15(9):e0239173.

174. Breslin N, Baptiste C, Miller R, Fuchs K, Goffman D, GyanfiBannerman C, et al. Coronavirus disease 2019 in pregnancy: early lessons. Am J Obstet Gynecol MFM. 2020;2(2):100111. https:// doi.org/10.1016/j.ajogmf.2020.100111.
175. Herraiz I, Folgueira D, Villalaín C, Forcén L, Delgado R, Galindo A. Universal screening for SARS-CoV-2 before labor admission during COVID-19 pandemic in Madrid. J Perinat Med. 2020 ; /j/ jpme.ahead-of-print/jpm-2020-0236/jpm-2020-0236.xml. https:// doi.org/10.1515/jpm-2020-0236.

176. Lu D, Sang L, Du S, Li T, Chang Y, Yang X-A. Asymptomatic COVID-19 infection in late pregnancy indicated no vertical transmission. J Med Virol. 2020. https://doi.org/10.1002/jmv.25927.

177. Sutton D, Fuchs K, D'Alton M, Goffman D. Universal screening for SARS-CoV-2 in women admitted for delivery. N Engl J Med. 2020;382(22):2163-4.

178. Vir Singh M, Shrivastava A, Maurya M, Tripathi A, Sachan R, Akhtar SS. Vertical transmission of SARS-CoV-2 from an asymptomatic pregnant woman in India. J Trop Pediatr. 2020; fmaa048. https://doi.org/10.1093/tropej/fmaa048.

179. Jing Q-L, Liu M-J, Zhang Z-B, Fang L-Q, Yuan J, Zhang A-R, et al. Household secondary attack rate of COVID-19 and associated determinants in Guangzhou, China: a retrospective cohort study. Lancet Infect Dis. 2020; S1473-3099(20)30471-0. https:// doi.org/10.1016/S1473-3099(20)30471-0.

180. Molina LP, Show S-K, Nickel A, Love JE. Prolonged detection of severe acute respiratory syndrome coronavirus 2 (SARS-CoV-2) RNA in an obstetric patient with antibody seroconversion. Obstet Gynecol. 2020.https://doi.org/10.1097/AOG. 0000000000004086

181. Cimolai N. Not all viral culture approaches are equal. Clin Infect Dis. 2020:ciaa1632. https://doi.org/10.1093/cid/ciaa1632.

182. Chan PK, To WK, Ng KC, Chiu RW, Ang IL, Tong YK, et al. Laboratory diagnosis of SARS. Emerg Infect Dis. 2004;10(5): 825-31.

183. Chan KH, Leo LLM, Cheng VCC, Guan Y, Hung IF, Kong J, et al. Detection of SARS coronavirus in patients with suspected SARS. Emerg Infect Dis. 2004;10(2):294-9.

184. Isakbaeva ET, Khetsuriani N, Beard RS, Peck A, Erdmann D, Monroe SS, et al. SARS-associated coronavirus transmission, United States. Emerg Infect Dis. 2004;10(2):225-31.

185. Hagman K, Hedenstierna M, Gille-Johnson P, Hammas B, Grabbe $\mathrm{M}$, Dillner J, et al. SARS-CoV-2 RNA in serum as predictor of severe outcome in COVID-19: a retrospective cohort study. Clin Infect Dis. 2020 ;ciaa1285. https://doi.org/10.1093/cid/ciaa1285.

186. Cimolai N. More data are required for incubation period, infectivity, and quarantine duration for COVID-19. Travel Med Infect Dis. 2020;27:101713. https://doi.org/10.1016/j.tmaid.2020. 101713.

187. Baud D, Greub G, Favre G, Gengler C, Jaton K, Dubruc E, et al. Second-trimester miscarriage in a pregnant woman with SARSCoVo-2 infection. JAMA. 2020;323(21):2198-200.

188. He Z, Fang Y, Zuo Q, Huang X, Lei Y, Ren X, et al. Vertical transmission and kidney damage in newborns from coronavirus disease 2019 infection pregnant mother. Int J Antimicrob Agents. 2020;57(2):106260. https://doi.org/10.1016/j.ijantijmicrag.2020. 106260.

189. Kalafat E, Yaprak E, Cinar G, Varli B, Ozisik S, Uzun C, et al. Lung ultrasound and computed tomographic findings in pregnant woman with COVID-19. Ultrasound Obstet Gynecol. 2020;55(6): $835-7$.

190. Lee DH, Lee J, Kim E, Woo K, Park HY, An J. Emergency cesarean section performed in a patient with confirmed severe acute respiratory syndrome coronavirus- 2 - a case report. Korean J Anesthesiol. 2020;73(4):347-51.

191. Liu W, Wang J, Li W, Zhou Z, Liu S, Rong Z. Clinical characteristics of 19 neonates born to mothers with COVID-19. Front Med. 2020;14(2):193-8.

192. Lv Y, Gu B, Chen Y, Hu S, Ruan T, Xu G, et al. No intrauterine vertical transmission in pregnancy with COVID-19: a case report. 
J Infect Chemother. 2020;S1341-321X(20)30266-X. https://doi. org/10.1016/j.jiac.2020.07.015.

193. Palalioglu RM, Mahammadaliyeva A, Erbiyik HI, Muhcu M. COVID-19 in third trimester may not be as scary as you think, it can be innocent: evaluating vertical transmission from a COVID19 positive asymptomatic pregnant woman with early membrane rupture. J Obstet Gynaecol Res. 2020. https://doi.org/10.1111/jog. 14584.

194. Rubio Lorente AM, Pola Guillén M, López Jimenez N, MorenoCid Garcia-Suelto M, Rodriguez Rodriguez E, Pascual Pedreño A. Study of amniotic fluid in pregnant women infected with SARSCoV-2 in first and second trimester: is there evidence of vertical transmission? J Matern Fetal Neonatal Med 2020 ;1-3. doi: https:// doi.org/10.1080/14767058.2020.1811669

195. Wang S, Guo L, Chen L, Liu W, Cao Y, Zhang J, et al. A case report of neonatal COVID-19 infection in China. Clin Infect Dis. 2020; ciaa225. https://doi.org/10.1093/cid/ciaa225.

196. Wang X, Zhou Z, Zhang J, Zhu F, Tang Y, Shen X. A case of 2019 novel coronavirus in a pregnant woman with preterm delivery. Clin Infect Dis. 2020 ;ciaa200. https://doi.org/10.1093/cid/ ciaa200.

197. Zambrano LI, Fuentes-Barahona IC, Bejarano-Torres DA, Bustillo C, Gonzales G, Vallecillo-Chinchilla G, et al. A pregnant woman with COVID-19 in Central America. Travel Med Infect Dis. 2020;36:101639. https://doi.org/10.1016/j.tmaid.2020. 101639.

198. Ryean GA, Purandare NC, McAuliffe FM, Hod M, Purandare CN. Clinical update on COVID-19 in pregnancy: a review article. J Obstet Gynaecol Res. 2020. https://doi.org/10.1111/jog.14321.

199. Pique-Regi R, Romero R, Tarca AL, Luca F, Xu Y, Alazizi A, et al. Does the human placenta express the canonical cell entry mediators for SARS-CoV-2? Elife. 2020;9:e58716.

200. Valdés G, Neves LAA, Anton L, Corthorn J, Chacón C, Germain AM, et al. Distribution of angiotensin-(1-7) and ACE2 in human placentas of normal and pathological pregnancies. Placenta. 2006;27(2-3):200-7.

201. Li M, Chen L, Zhang J, Xiong C, Li X. The SARS-CoV-2 receptor of ACE2 expression of maternal-fetal interface and fetal organs by single-cell transcriptome study. PLoS One. 2020;15(4): e0230295.

202. Lü M, Qiu L, Jia G, Guo R, Leng Q. Single-cell expression profiles of ACE2 and TMPRSS2 reveals potential vertical transmission and fetus of SARS-CoV-2. Aging. 2020;12(20):19880-97. https://doi.org/10.18632/aging.104015.

203. Jing H, Ackerman WE IV, Zhao G, El Helou Y, Buhimschi CS, Buhimschi IA. Connecting the dots on vertical transmission of SARS-CoV-2 using protein-protein interaction network analysis - potential roles of placental ACE2 and ENDOU. Placenta. 2020;104:16-9.

204. Cimolai N. Conflicting evidence on vertical transmission and maternal SARS-CoV-2 infection. CMAJ. 2020;192(47):E1547.

205. Penfield CA, Brubaker SG, Limaye MA, Lighter J, Ratner AJ, Thomas KM, et al. Detection of SARS-CoV-2 in placental and fetal membrane samples. Am J Obstet Gynecol MFM. 2020;2(3): 100133. https://doi.org/10.1016/j.ajogmf.2020.100133.

206. Patanè L, Morotti D, Giunta MR, Sigismondi C, Piccoli MG, Frigerio L, et al. Vertical transmission of COVID-19: SARSCoV-2 RNA on the fetal side of the placenta in pregnancies with COVID-19 positive mothers and neonates at birth. Am J Obstet Gynecol MFM. 2020;2(3):100145. https://doi.org/10.1016/j. ajogmf.2020.100145

207. Algarroba GN, Rekawek P, Vahanian SA, Khullar P, Palaia T, Peltier MR, et al. Visualization of SARS-CoV-2 virus invading the human placenta using electron microscopy. Am J Obstet Gynecol. 2020. https://doi.org/10.1016/j.ajog.2020.05.023.
208. Mulvey JJ, Magro CM, Ma LX, Nuovo GJ, Baergen RN. Analysis of complement deposition and viral RNA in placentas of COVID19 patients. Ann Diagn Pathol. 2020;46:151530. https://doi.org/ 10.1016/j.anndiagpath.2020.151530.

209. Shanes ED, Mithal LB, Otero S, Azad HA, Miller ES, Goldstein JA. Placental pathology in COVID-19. Am J Clin Pathol. 2020;aqaa089. https://doi.org/10.1093/acjp/aqaa089.

210. Colling ME, Kanthi Y. COVID-19-associated coagulopathy: an exploration of mechanisms. Vasc Med. 2020 ;1358863X20932640.https://doi.org/10.1177/ $1358863 X 20932640$.

211. Costanzo L, Palumbo FP, Ardita G, Antignani PL, Arosio E, Failla G. Coagulopathy, thromboembolic complications and the use of heparin in COVID-19 pneumonia. J Vasc Surg Venous Lymphat Disord. 2020;S2213-333X(20)30342-5. https://doi.org/10.1016/j/ jvsv.2020.05.018.

212. Baergen RN, Heller DS. Placental pathology in COVID-19 positive mothers: preliminary findings. Pediatr Dev Pathol. 2020;23(3):177-80.

213. Shuo C, Bo H, Danju L, Xiang L, Fan Y, Yin Z, et al. Pregnant women with new coronavirus infection: a clinical characteristics and placental pathological analysis of three cases. Zhonghua Bing Li Xue Za Zhi. 2020;49:E005.

214. Menter T, Mertz KD, Jiang S, Chen H, Monod C, Tzankov A, et al. Placental pathology findings during and after SARS-CoV-2 infection: features of villitis and malperfusion. Pathobiology. 2020 ;1-9. https://doi.org/10.1159/000511324.

215. Hsu AL, Guan M, Johannesen E, Stephens AJ, Khaleel N, Kagan $\mathrm{N}$, et al. Placental SARS-CoV-2 in a pregnant woman with mild COVID-19 disease. J Med Virol. 2020. https://doi.org/10.1002/ $\mathrm{jmv} / 2638$.

216. Ferraiolo A, Barra F, Kratochwila C, Paudice M, Gaetano Vellone V, Godano E, et al. Report of positive placental swabs for SARSCoV-2 in an asymptomatic pregnant woman with COVID-19. Medicina (Kaunas). 2020;56(6):E306.

217. Komine-Aizawa S, Takada K, Hayakawa S. Placental barrier against COVID-19. Placenta. 2020;99:45-9.

218. Sisman J, Jaleel MA, Moreno W, Rajaram V, Collins RRJ, Savani $\mathrm{RC}$, et al. Intrauterine transmission of SARS-CoV-2 infection in a preterm infant. Pediatr Infect Dis J. 2020. https://doi.org/10.1097/ INF0000000000002815.

219. Schwartz DA, Morotti D. Placental pathology of COVID-19 with and without fetal and neonatal infection: trophoblast necrosis and chronic histiocytic intervillositis as risk factors for transplacental transmission of SARS-CoV-2. Viruses. 2020;12(11):E1308.

220. Shende P, Gaikwad P, Gandhewar M, Ukey P, Bhide A, Patel V, et al. Persistence of SARS-CoV-2 in the first trimester placenta leading to transplacental transmission and fetal demise from an asymptomatic mother. Hum Reprod. 2020;deaa367. https://doi. org/10.1093/humrep/deaa367.

221. Facchetti F, Bugatti M, Drera E, Tripodo C, Sartori E, Cancila V, et al. SARS-CoV-2 vertical transmission with adverse effects on the newborn revealed through integrated immunohistochemical, electron microscopy and molecular analyses of placenta. EBioMedicine. 2020;59:102951. https://doi.org/10.1016/j.ebiom. 2020.10251

222. Debelenko L, Katsyv I, Chong AM, Peruyero L, Szabolcs M, Uhlemann A-C. Trophoblast damage with acute and chronic intervillositis: disruption of placental barrier by SARS-CoV-2. Hum Pathol. 2020; S0046-8177(20)30256-2. https://doi.org/10. 1016/j.humpath.2020.12.004.

223. Garcia-Manau P, Garcia-Ruiz I, Rodo C, Sulleiro E, Maiz N, Catalan M, et al. Fetal transient skin edema in two pregnant women with coronavirus disease 2019 (COVID-19). Obstet Gynecol. 2020. https://doi.org/10.1097/AOG.0000000000004059. 
224. Rivera-Hernandez P, Nair J, Islam S, Davidson L, Chang A, Elberson V. Coronavirus disease 2019 in a premature infant: vertical transmission and antibody response or lack thereof. AJP Rep. 2020;10(3):e224-7.

225. Bandyopadhyay T, Sharma A, Kumari P, Maris A, Choudhary R. Possible early vertical transmission of COVID-19 from an infected pregnant female to her neonate: a case report. J Trop Pediatr. 2020;fmaa094. https://doi.org/10.1093/tropej/fmaa094.

226. Gao J, Li W, Hu W, Wei Y, Wu J, Luo X, et al. Disappearance of SARS-CoV-2 antibodies in infants born to women with COVID19, Wuhan, China. Emerg Infect Dis. 2020;26(10):2491-4. https://doi.org/10.3201/eid2610.202328.

227. Marzollo R, Aversa S, Prefumo F, Saccani B, Rodriguez Perez C, Sartori E, et al. Possible coronavirus disease 2019 pandemic and pregnancy: vertical transmission is not excluded. Pediatr Infect Dis J. 2020. https://doi.org/10.1097/INF.0000000000002816.

228. Cavicchiolo ME, Trevisanuto D, Lolli E, Mardegan V, Saieva AM, Franchin E, et al. Universal screening of high-risk neonates, parents, and staff at a neonatal intensive care unit during the SARS-CoV-2 pandemic. Eur J Pediatr. 2020. https://doi.org/10. 1007/s00431-020-03765-7.

229. Toner LE, Gelber SE, Pena JA, Fox NS, Rebarber A. A case report to assess passive immunity in a COVID positive pregnant patient. Am J Perinatol. 2020. https://doi.org/10.1055/s-0040-1715643.

230. Chany C, Moscovici O, Lebon P, Rousset S. Association of coronavirus infection with neonatal necrotizing enterocolitis. Pediatrics. 1982;69(2):209-14.

231. Resta S, Luby JP, Rosenfeld CR, Siegel JD. Isolation and propagation of a human enteric coronavirus. Science. 1985;229(4717): 978-81.

232. Vaucher YE, Ray CG, Minnich LL, Payne CM, Beck D, Lowe P. Pleomorphic, enveloped, virus-like particles associated with gastrointestinal illness in neonates. J Infect Dis. 1982;145(1):27-36.

233. Kaiser L, Regamey N, Roiha H, Deffernez C, Frey U. Human coronavirus NL63 associated with lower respiratory tract symptoms in early life. Pediatr Infect Dis J. 2005;24(11):1015-7.

234. Gerna G, Percivalle E, Sarasini A, Campanini G, Piralla A, Rovida F, et al. Human respiratory coronavirus HKU1 versus other coronavirus infections in Italian hospitalised patients. J Clin Virol. 2007;38(5):244-50.

235. Gagneur A, Sizun J, Vallet S, Legr MC, Picard B, Talbot PJ. Coronavirus-related nosocomial viral respiratory infections in a neonatal and paediatric intensive care unit: a prospective study. $\mathrm{J}$ Hosp Infect. 2002;51(1):59-64.

236. Sizun J, Soupre D, Legrand MC, Giroux JD, Rubio S, Chastel C, et al. Pathogenic role of coronavirus in pediatric intensive care: retrospective analysis of 19 positive samples with indirect immunofluorescence. Arch Pediatr. 1994;1(5):477-80.

237. Farghaly MAA, Kupferman F, Castillo F, Kim RM. Characteristics of newborns born to SARS-CoV-2-positive mothers. Am J Perinatol. 2020. https://doi.org/10.1055/s-0040171862.

238. Goldshtrom N, Vargas D, Vasquez A, Kim F, Desai K, Turner $\mathrm{ME}$, et al. Neonates with complex cardiac malformation and congenital diaphragmatic hernia born to SARS-CoV-2 positive women - a single center experience. World J Pediatr Congenit Heart Surg. 2020;2150135120950256. https://doi.org/10.1177/ 2150135120950256.

239. Griffin I, Benarba F, Peters C, Oyelese Y, Murphy T, Contreras D, et al. The impact of COVID-19 infection on labor and delivery, newborn nursery, and neonatal intensive care unit: prospective observational data from a single hospital infection. Am J Perinatol. 2020. https://doi.org/10.1055/s-0040-1713416.

240. Liu P, Zheng J, Yang P, Wang X, Wei C, Zhang S, et al. The immunologic status of newborns born to SARS-CoV-2-infected mothers in Wuhan, China. J Allergy Clin Immunol. 2020;146(1): 101-109e1.

241. Salvatore CM, Han J-Y, Acker KP, Tiwari P, Jin J, Brandler M, et al. Neonatal management and outcomes during the COVID-19 pandemic: an observation cohort study. Lancet Child Adolesc Health. 2020;S2352-4642(20)30235-2. https://doi.org/10.1016/ S2352-4642(20)30235-2.

242. Vintzileos WS, Muscat J, Hoffmann E, John NS, Vertichio R, Vintzileos AM, et al. Screening all pregnant women admitted to labor and delivery for the virus responsible for coronavirus disease 2019. Am J Obstet Gynecol. 2020;223(2):284-6.

243. Zheng Q-X, Jiang X-M, Lin Y, Liu G-H, Lin Y-P, Kang T-L, et al. The influence of psychological response and security sense on pregnancy stress during the outbreak of coronavirus disease 2019: a mediating model. J Clin Nurs. 2020. https://doi.org/10. 1111/jocn.15460.

244. Cojocaro L, Crimmins S, Sundararajan S, Goetzinger K, Elsamadicy E, Lankford A, et al. An initiative to evaluate the safety of maternal bonding in patients with SARS-CoV-2 infection. J Matern Fetal Neonatal Med. 2020; 1-7. https://doi.org/10. 1080/14767058.2020.1828335.

245. Gale C, Quigley MA, Placzek A, Knight M, Ladhani S, Draper ES, et al. Characteristics and outcomes of neonatal SARS-CoV-2 infection in the UK: a prospective national cohort study using active surveillance. Lancet Child Adolesc Health. 2020; S23524642(20)30342-4. https://doi.org/10.1016/S2352-4642(20) 30342-4.

246. Abourida Y, Rebahi H, Oussayeh I, Chichou H, Fakhir B, Soummani A, et al. Management of severe COVID-19 in pregnancy. Case Rep Obstet Gynecol. 2020;2020:8852816. https:// doi.org/10.1155/2020/8852816.

247. Kolkova Z, Bjurström MF, Länsberg J-K, Svedas E, Andrada Hamer M, Hansson SR, et al. Obstetric and intensive-care strategies in a high-risk pregnancy with critical respiratory failure due to COVID-19: a case report. Case Rep Womens Health. 2020;27: e00240.

248. Lumba R, Remon J, Louie M, Quan M, Verma S, Rigaud M, et al. Neonate born to a mother with a diagnosis of suspected intraamniotic infection versus COVID-19 or both. Case Rep Pediatr. 2020;2020:8886800. https://doi.org/10.1155/2020/8886800.

249. Zheng T, Guo J, He W, Wang H, Yu H, Ye H. Coronavirus disease 2019 (COVID-19) in pregnancy: 2 case reports on maternal and neonatal outcomes in Yichang city, Hubei Province, China. Medicine. 2020;99(29):e21334.

250. Fernández Colomer B, Sánchez-Luna M, de Alba Romero C, Alarcón A, Souto AB, Camba Longueira F, et al. Neonatal infection due to SAR-CoV-2: an epidemiological study in Spain. Front Pediatr. 2020;8:580584. https://doi.org/10.3389/fped.2020. 580584.

251. Hamood Alwardi T, Ramdas V, Al Yahmadi M, Al Aisari S, Bhandari S. Saif Al Hashami H, et al. Is vertical transmission of SARS-CoV-2 infection possible in preterm triplet pregnancy? A case series. Pediatr Infect Dis J. 2020. https://doi.org/10.1097/ INF.0000000000002926.

252. Xiao F, Chen B, Xiao T, Lee SK, Yan K, Hu L. Children with SARS-CoV-2 infection during an epidemic in China (outside of Hubei province). Ann Transl Med. 2020;8(14):849.

253. Dumitriu D, Emeruwa UN, Hanft E, Liao GV, Ludwig E, Walzer $\mathrm{L}$, et al. Outcomes of neonates born to mothers with severe acute respiratory syndrome coronavirus 2 infection at a large medical center in New York City. JAMA Pediatr. 2020. https://doi.org/10. 1001/jamapediatrics.2020.4298.

254. Liu X, Xie R, Li W, Guo Y, Zhang B, Zhang Y, et al. Clinical and epidemiologic features of 46 children under 1 year old with coronavirus disease 2019 (COVID-19) in Wuhan, China: a descriptive 
study. J Infect Dis. 2020;jiaa472. https://doi.org/10.1093/infdis/ jiaa472.

255. Mehta H, Ivanovic S, Cronin A, VanBrunt L, Mistry N, Miller R, et al. Novel coronavirus-related acute respiratory distress syndrome in a patient with twin pregnancy: a case report. Case Rep Women's Health. 2020;27:e00220.

256. Dima M, Enatescu I, Craina M, Petre I, Radu Iacob E, Iacob D. First neonates with severe acute respiratory syndrome 2 infection in Romania: three case reports. Medicine. 2020;99(33):e21284.

257. Hopwood AJ, Jordan-Villegas A, Gutierrez LD, Cowart MC, Vega-Montalvo W, Leung Cheung W, et al. SARS-CoV-2 pneumonia in a newborn treated with remdesivir and COVID-19 convalescent plasma. J Pediatric Infect Dis Soc. 2020;piaa165. https:// doi.org/10.1093/jpids/piaa165.

258. Kalamdani P, Kalathingal T, Manerkar S, Mondkar J. Clinical profile of SARS-CoV-2 infected neonates from a tertiary government hospital in Mumbai, India. Indian Pediatr 2020 ;S097475591600250

259. Kenan Kanburoglu M, Tayman C, Yekta Oncel M, Mungan Akin I, Can E, Demir N, et al. A mulitcentred study on epidemiological and clinical characteristics of 37 neonates with communityacquired COVID-19. Pediatr Infect Dis J. 2020;39(10):e297-302.

260. Olivini N, Calò Carducci FI, Santilli V, De Ioris MA, Scarselli A, Alario D, et al. A neonatal cluster of novel coronavirus disease 2019: clinical management and considerations. Ital J Pediatr. 2020;46(1):180.

261. Bordbar A, Kashaki M, Rezaei F. Vertical transmission of COVID-19 in a 1-day-old neonate. Travel Med Infect Dis. 2020;38:101879. https://doi.org/10.1016/j.tmaid.2020.101879.

262. Vivanti A, Vauloup-Fellous C, Prevot S, Zupan V, Suffee C, Do Cao J, et al. Transplacental transmission of SARS-CoV-2 infection. Nat Commun. 2020;11(1):3572.

263. Buonsenso D, Costa S, Sanguinetti M, Cattani P, Posteraro B, Marchetti S, et al. Neonatal late onset infection with severe acute respiratory syndrome coronavirus 2 . Am J Perinatol. 2020. https:// doi.org/10.1055/s-0040-1710541.

264. Govind A, Essien S, Karthikeyan A, Fakokunde A, Janga D, Yoong W, et al. Novel coronavirus COVID-19 in late pregnancy: outcomes of first nine cases in an inner city London hospital. Eur J Obstet Gynecol. 2020; S0301-2115(20)30257-8. https://doi.org/ 10.1016/j.ejogrb.2020.05.004.

265. Mithal LB, Machut KZ, Muller WJ, Kociolek LK. SARS-CoV-2 infection in infants less than 90 days old. J Pediatr. 2020;224:150 2.

266. Slaats MALJ, Versteylen M, Gast KB, Oude Minnink BB, Pas $\mathrm{SD}$, Bentvelsen RG, et al. Case report of a neonate with high viral SARS-CoV-2 loads and long-term virus shedding. J Infect Public Health. 2020;S1876-0341(20)30710-3;10.1016/ j.jiph.2020.10.013.

267. Trieu C, Poole C, Cron RQ, Hallman M, Rutledge C, Bliton K, et al. Severe neonatal coronavirus disease 2019 presenting as acute respiratory distress syndrome. Pediatr Infect Dis J. 2020. https:// doi.org/10.1097/INF.0000000000002864.

268. Zeng L, Xia S, Yuan W, Yan K, Xiao F, Shao J, et al. Neonatal early-onset infection with SARS-CoV-2 in 33 neonates born to mothers with COVID-19 in Wuhan, China. JAMA Pediatr. 2020;2020:e200878. https://doi.org/10.1001/jamapediatrics. 2020.0878.

269. Piersigilli F, Carkeek K, Hocq C, van Grambezen B, Hubinont C, Chatzis O, et al. COVID-19 in a 26-week preterm neonate. Lancet Child Adolesc Health. 2020;4(6):476-8.

270. Gordon M, Kagalwala T, Rezk K, Rawlingston C, Ahmed MI, Guleri A. Rapid systematic review of neonatal COVID-19 including a case of presumed vertical transmission. BMJ Paediatr Open. 2020;4:e000718.
271. Alzamora MC, Paredes T, Caceres D, Webb CM, Valdez LM, La Rosa M. Severe COVID-19 during pregnancy and possible vertical transmission. Am J Perinatol. 2020. https://doi.org/10.1055/s0040-1710050.

272. Yu N, Li W, Kang Q, Xiong Z, Wang S, Lin X, et al. Clinical features and obstetric and neonatal outcomes of pregnant patients with COVID-19 in Wuhan, China: a retrospective, single-centre, descriptive study. Lancet Infect Dis. 2020;20(5):559-64.

273. Otto WR, Geoghegan S, Posch L, Bell LM, Coffin SE, Sammons JS, et al. The epidemiology of SARS-CoV-2 in a pediatric healthcare network in the United States. J Pediatric Infect Dis Soc. 2020;piaa074. https://doi.org/10.1093/jpids/piaa074.

274. Chaćon-Aguilar R, Osorio-Cámara JM, Sanjurjo-Jimenez I, González-González C, López-Carnero J, Pérez-Moneo B. COVID-19: fever syndrome and neurological symptoms in a neonate. An Pediatr (Barc). 2020;92(6):373-4.

275. Kamali Aghdam M, Jafari N, Eftekhari K. Novel coronavirus in a 15-day-old neonate with clinical signs of sepsis, a case report. Infect Dis Ther. 2020;52(6):427-9.

276. Moolasart V, Wongsawat J, Phokhom P, Thienthong V. Favipravir-based regimen for coronavirus disease 2019 pneumonia for a 47-day-old male newborn. SAGE Open Med Case Rep. 2020;8:2050313X20964046. https://doi.org/10.1177/ 2050313X20964046.

277. Rong Q, Abubakar K. A newborn with coronavirus (COVID-19) disease: a brief report. J Neonatal-Perinatal Med. 2020. https://doi. org/10.3233/NPM-200489.

278. Wardell H, Campbell JI, VanderPluym C, Dixit A. SARS-CoV-2 infection in febrile neonates. J Pediatric Infect Dis Soc. 2020;9(5): 630-5.

279. Blitz MJ, Rochelson B, Rausch AC, Solmonovich R, Shan W, Combs A, et al. Universal testing for coronavirus disease 2019 in pregnant women admitted for delivery: prevalence of peripartum infection and rate of asymptomatic carriers at four New York hospitals within an integrated healthcare system. Am J Obstet Gynecol MFM. 2020;2(3):100169. https://doi.org/10.1016/j. ajogmf.2020.100169.

280. Figueiredo R, Tavares S, Moucho M, Ramalho C. Systematic screening for SARS-CoV-2 in pregnant women admitted for delivery in a Portuguese maternity. J Perinat Med. $2020 ; / \mathrm{j} /$ jpme.ahead-of-print/jpm-2020-0387/jpm-2020-0387.xml. https:// doi.org/10.1515/jpm-2020-0387.

281. Rolnik DL, Korman TM, Rindt A, Stuart RL, Giles ML, Rawlins $\mathrm{J}$, et al. Coronavirus testing in women attending antenatal care. Women Birth. 2020 ;S1871-5192(20)303055-3. https://doi.org/ 10.1016/j.wombi.2020.09.024.

282. Ahn JY, An S, Sohn Y, Cho Y, Hyun JH, Baek YJ, et al. Environmental contamination in the isolation rooms of COVID19 patients with severe pneumonia requiring mechanical ventilation or high-flow oxygen therapy. J Hosp Infect. 2020;S01956701(20)30401-1. https://doi.org/10.1016/j.jhin.2020.08.01.

283. Jiang F-C, Jiang X-L, Wang Z-G, Meng Z-H, Shao S-F, Anderson $\mathrm{BD}$, et al. Detection of severe acute respiratory syndrome coronavirus 2 RNA on surfaces in quarantine rooms. Emerg Infect Dis. 2020;26(9):2162-4. https://doi.org/10.3201/eid2609.201435.

284. Wu S, Wang Y, Jin X, Tian J, Liu J, Mao Y. Environmental contamination by SARS-CoV-2 in a designated hospital for coronavirus disease 2019. Am J Infect Control. 2020. https://doi.org/ 10.1016/j.ajic.2020.05.003.

285. Ye G, Lin H, Chen L, Wang S, Zeng Z, Wang W, et al. Environmental contamination of SARS-CoV-2 in healthcare premises. J Inf Secur. 2020. https://doi.org/10.1016/j/jinf.2020.04. 034.

286. Yung CF, Kam KQ, Wong MSY, Maiwald M, Tan YK, Tan BH, et al. Environment and personal protective equipment tests for 
SARS-CoV-2 in the isolation room of an infant with infection. Ann Intern Med. 2020. https://doi.org/10.7326/M20-0942.

287. Herman JA, Urits I, Kaye AD, Urman RD, Viswanath O. COVID19: obstetric anesthesia care considerations. J Clin Anesth. 2020;65:109885. https://doi.org/10.1016/j.jclinane.2020.109885.

288. Cimolai N Re-analysis of quarantine for COVID-19 with emerging data. Am J Obstet Gynecol MFM 2020 (In press)

289. Krupp KF, Madhivarian P, Perez-Velez CM. Should qualitative RT-PCR be used to determine release from isolation of COVID19 patients? J Inf Secur. 2020;S-0163-4453(20)30411; 10.1016.j.jinf.2020.06.030.

290. Aziz A, Zork N, Aubey JJ, Baptiste CD, D’Alton ME, Emeruwa $\mathrm{UN}$, et al. Telehealth for high-risk pregnancies in the setting of the COVID-19 pandemic. Am J Perinatol. 2020;37(8):800-8.

291. Pastick KA, Nicol MR, Smyth E, Zash R, Boulware DR, Rajasingham R, et al. A systematic review of treatment and outcomes of pregnant women with COVID-19 - a call for clinical trials. Open Forum Infect Dis. 2020;7(9):ofaa350.

292. Narang K, Elrefaei A, Wyatt MA, Warner LL, Teles Abrao Trad A, Segura LG, et al. Fetal surgery in the era of SARS-CoVo-2 pandemic: a single institution review. Mayo Clin Proc Innov Qual Outcomes. 2020. https://doi.org/10.1016/j.mayocpiqo.2020.08. 001

293. Iwamoto A, Tung R, Ota T, Hosokawa S, Matsui M. Challenges to neonatal care in Cambodia amid the COVID-19 pandemic. Glob Health Med. 2020;2(2):142-4

294. De Rose DU, Auriti C, Landolfo F, Capolupo I, Salvatori G, Ranno S, et al. Reshaping of neonatal intensive care units to avoid the spread of COVID-19 to high-risk infants. Infect Control Hosp Epidemiol. 2020;24:1-8. https://doi.org/10.1017/ice.2020.310.

295. Cavicchiolo ME, Doglioni N, Ventola MA, Biban P, Baraldi E, Trevisanuto D. Neonatal emergency transport system during COVID-19 pandemic in the Veneto Region: proposal for standard operating procedures. Pediatr Res. 2020. https://doi.org/10.1038/ s41390-020-0937-z.

296. Simon A, Hübner J, Knuf M, Hufnagel M, Berner R. Management of care for neonates born to SARS-CoV-2 positive women with or without clinical symptoms (COVID-19). Klin Padiatr. 2020;232(4):173-7.

297. Louchet M, Sibiude J, Peytavin G, Picone O, Tréluyer J-M, Mandelbrot L. Placental transfer and safety in pregnancy of medications under investigation to treat coronavirus disease 2019. Am J Obstet Gynecol. 2020;2(3):100159. https://doi.org/10.1016/j. ajogmf.2020.100159.

298. Cimolai N. The semantics of airborne microbial spread and environmental relevance: back to Anderson and Cox. Environ Res. 2020;16:110448. https://doi.org/10.1016/j.envres.2020.110448.

299. Chivers BR, Garad RM, Boyle JA, Skouteris H, Teede HJ, Harrison CL. Perinatal distress during COVID-19: a thematic analysis of an online parenting forum. J Med Internet Res. 2020. https://doi.org/10.2196/22002.

300. Farrell T, Reagu S, Mohan S, Elmidany R, Qaddoura F, Elfadil Ahmed E, et al. The impact of the COVID-19 pandemic on the perinatal mental health of women. J Perinat Med. 2020;/j/ jpme.ahead-of-print/jpm-2020-0415/jpm-2020-0415.xml. https:// doi.org/10.1515/jpm-2020-0415.

301. Mayopoulos G, Ein-Dor T, Li KG, Chan SJ, Dekel S. Giving birth under hospital visitor restrictions: heightened acute stress in childbirth in COVID-19 positive women. Res Sq. 2020;rs.3.rs-112882. https://doi.org/10.21203/rs.3.rs-112882/v.1.

302. Overbeck G, Hauskov Graungaard A, Scheel Rasmussen I, Hogsgaard Andersen J, Kirk Ertmann R, Kragstrup J, et al. Pregnant women's concerns and antenatal care during COVID19 lock-down of the Danish society. Dan Med J. 2020;67(12): A06200449.
303. Papofsky S, Noor A, Leavens-Maurer J, Quintos-Alagheband ML, Mock A, Vinci A, et al. Impact of maternal severe acute respiratory syndrome coronavirus 2 detection on breastfeeding due to infant separation at birth. J Pediatr. 2020;226:64-70.

304. Perrine CG, Chiang KV, Anstey EH, Grossniklaus DA, Boundy EO, Sauber-Schatz EK, et al. Implementation of hospital practices supportive of breastfeeding in the context of COVID-19 - United States, July 15-August 20, 2020. MMWR Morb Mortal Wkly Rep. 2020;69(47):1767-70.

305. Egerup P, Fich Olsen L, Hellerung Christiansen A-M, Westergaard D, Rosenbek Severinsen E, Vauvert Römmelmayer Hviid K, et al. Severe acute respiratory syndrome coronavirus 2 (SARS-CoV-2) antibodies at delivery in women, partners, and newborns. Obstet Gynecol. 2020. https://doi.org/10. 1097/AOG.0000000000004199.

306. Panon G, Tache S, Labie C. Respective stability of rotavirus and coronavirus in bovine milk. Lait. 1988;68(1):49-64.

307. Panon G, Tache S, Labie C. Antiviral substances in raw bovine mild active against bovine rotavirus and coronavirus. J Food Prot. 1987;50(10):862-6.

308. Callebaut P, Cox E, Pensaert M, Van Deun K. Induction of milk IgA antibodies by porcine respiratory coronavirus infection. In: Cavanaugh D, Brown TDK, editors. Coronaviruses and Their Diseases. New York: Plenum Press; 1990. p. 421-8.

309. Ikemori Y, Ohta M, Umeda K, Icatlo FC Jr, Kuroki M, Yokoyama $\mathrm{H}$, et al. Passive protection of neonatal calves against bovine coronavirus-induced diarrhea by administration of egg yolk or colostrum antibody powder. Vet Microbiol. 1997;58(2-4):105-11.

310. Castilla J, Pintado D, Sola I, Sáchez-Morgado JM, Enjunes L. Engineering passive immunity in transgenic mice secreting virus-neutralizing antibodies in milk. Nat Biotechnol. 1998;16(4):349-54.

311. Kolb AF, Pewe L, Webster J, Perlman S, Whitelaw CB, Siddell SG. Virus-neutralizing monoclonal antibody expressed in milk of transgenic mice provides full protection against virus-induced encephalitis. J Virol. 2001;75(6):2803-9.

312. Reed SE. The behavior of recent isolates of human respiratory coronavirus in vitro and in volunteers: evidence of heterogeneity among 229E-related strains. J Med Virol. 1984;13(2):179-92.

313. Callow KA. Effect of specific humoral immunity and some nonspecific factors on resistance of volunteers to respiratory coronavirus infection. J Hyg. 1985;95(1):173-89.

314. MacAdam S, Cimolai N. Anti-Mycoplasma pneumoniae secretory antibody in human breast milk. Diagn Microbiol Infect Dis. 2002;43(3):247-50.

315. Cimolai N. Defining protective epitopes for COVID-19 vaccination models. J Med Virol. 2020. https://doi.org/10.1002/jmv. 25876.

316. Imai M, Iwatsuki-Horimoto K, Hatta M, Loeber S, Halfmann PJ, Nakajima N, et al. Syrian hamsters as a small animal model for SARS-CoV-2 infection and countermeasure development. Proc Natl Acad Sci U S A. 2020; 202009799. https://doi.org/10.1073/ pnas.2009799117.

317. Jafari R, Jonaidi-Jafari N, Dehghanpoor F, Saburi A. Convalescent plasma therapy in a pregnant COVID-19 patient with a dramatic clinical and imaging response: a case report. World J Radiol. 2020;12(7):137-41.

318. Cimolai N. A minimalist strategy towards temporarily defining protection for COVID-19. SN Compr Clin Med. 2020;19:1-8. https://doi.org/10.1007/s42399-020-00533-4.

319. Cimolai N. Immune instincts and maternal intelligence from comparative microbiology for COVID-19. SN Compr Clin Med. 2020; 1-14. https://doi.org/10.1007/s42399-020-00634-0.

320. Pace RM, Williams JE, Järvinen KM, Belfort MB, Dw Pace C, Lackey KA, et al. COVID-19 and human milk: SARS-CoV-2, antibodies, and neutralizing capacity. medRxiv. 
2020;2020.09.16.20196071. https://doi.org/10.1101/2020.09.16. 20196071.

321. Zhu C, Liu W, Su H, Li S, Shereen MA, Lv Z, et al. Breastfeeding risk from detectable severe acute respiratory syndrome coronavirus 2 in breastmilk. J Inf Secur. 2020;S0163-4453(20)30379-0. https://doi.org/10.1016/j.jinf.2020.06.001.

322. Hijona Elósegui JJ, Carballo Garcia AL, Fernández Risquez AC, Bermúdez Quintana M, Expósito Montes JF. Does the maternalfetal transmission of SARS-CoV-2 occur during pregnancy? Rev Clin Esp. 2020 ;S0014-2565(20)30156-9. https://doi.org/10.1016/ j.rce.2020.06.001.

323. Lackey KA, Pace RM, Williams JE, Bode L, Donovan SM, Järvinen AE, et al. SARS-CoV-2 and human milk: what is the evidence? Matern Child Nutr. 2020;16(4):e13032. https://doi. org $/ 10.1111 / \mathrm{mcn} .13032$.

324. Duan S-M, Zhao X-S, Wen R-F, Huang J-J, Pi G-H, Zhang S-X, et al. Stability of SARS coronavirus in human specimens and environment and its sensitivity to heating and UV irradiation. Biomed Environ Sci. 2003;16(3):246-55.

325. Darnell MER, Subbarao K, Feinstone SM, Taylor DR. Inactivation of the coronavirus that induces severe acute respiratory syndrome. SARS-CoV J Virol Methods. 2004;121(1):8591.

326. Leclerq I, Batéjat C, Burguière AM, Manuguerra J-C. Heat inactivation of the Middle East Respiratory Syndrome coronavirus. Influenza Other Respir Viruses. 2014;8(5):585-6.

327. Chin AWH, Chu JTS, Perera MRA, Hui KPY, Yen H-L, Chan $\mathrm{MCW}$, et al. Stability of SARS-CoV-2 in different environmental conditions. Lancet Microbe. 2020;1(1):E10.

328. Unger S, Christie-Holmes N, Guvenc F, Budylowski P, Mubareka $\mathrm{S}$, Gray-Owen SD, et al. Holder pasteurization of donated human milk is effective in inactivating SARS-CoV-2. CMAJ. 2020;192: E871-4.

329. Ford JE, Law BE, Marshall VM, Reiter B. Influence of the heat treatment of human milk on some of its protective constituents. J Pediatr. 1977;90(1):29-35.

330. Evans TJ, Ryley HC, Neale LM, Dodge JA, Lewarne VM. Effect of storage and heat on antimicrobial proteins in human milk. Arch Dis Child. 1978;53(3):239-41.

331. Björkstén B, Burman LG, De Cháteau P, Fredrikzon B, Gothefors L, Hernell O. Collecting and banking human milk: to heat or not to heat? BMJ. 1980;281(6243):765-9.

332. Wills ME, Han VE, Harris DA, Baum JD. Short-time low-temperature pasteurization of human milk. Early Hum Dev. 1982;7(1):71-80.

333. Goldblum RM, Dill CW, Albrecht RB, Alford ES, Garza C, Goldman AS. Rapid high-temperature treatment of human milk. J Pediatr. 1984;104(3):380-5.
334. Chantry CJ, Israel-Ballard K, Moldoveanu Z, Peerson J, Coutsoudis A, Sibeko L, et al. Effect of flash-heat treatment on immunoglobulins in breastmilk. J Acquir Immune Defic Syndr. 2009;51(3):264-7.

335. Akinbi H, Meinzen-Derr J, Auer C, Ma Y, Pullum D, Kusano R, et al. Alterations in the host defense properties of human milk following prolonged storage or pasteurization. JPGN. 2010;51(3):347-52.

336. Chang J-C, Chen C-H, Fang L-J, Tsai C-R, Chang Y-C, Wang T$\mathrm{M}$. Influence of prolonged storage process, pasteurization, and heat treatment on biologically-active human milk proteins. Pediatr Neonatol. 2013;54(6):360-6.

337. Czank C, Prime DK, Hartmann B, Simmer K, Hartmann PE. Retention of the immunological proteins of pasteurized human milk in relation to pasteurizer design and practice. Pediatr Res. 2009;66(4):374-9.

338. Contador R, Delgado-Adámez J, Delgado FJ, Cava R, Ramírez R. Effect of thermal pasteurization or high pressure processing on immunoglobulin and leukocyte contents of human milk. Int Dairy J. 2013;32(1):1-5.

339. Sousa SG, Delgadillo I, Saraiva JA. Effect of thermal pasteurisation and high-pressure processing on immunoglobulin content and lysozyme and lactoperoxidase activity in human colostrum. Food Chem. 2014;151:79-85.

340. Api O, Sen C, Debska M, Saccone G, D'Antonio F, Volpe N, et al. Clinical management of coronavirus disease 2019 (COVID-19) in pregnancy: recommendations of WAPM-World Association of Perinatal Medicine. J Perinat Med. 2020;/j/jpme.ahead-of-print/ jpm-2020-0265/jpm-2020-0265.xml; 10.1515/jpm-2020-0265.

341. Centres for Disease Control and Prevention, USA. Considerations for inpatient obstetric healthcare settings. 2020. https://www.cdc. gov/coronavirus/2019-ncov/hcp/inpatient-obstetric-healthcareguidance.html. Accessed 23 Dec 2020.

342. Geneva Foundation for Medical Research and Education. Coronavirus (COVID-19) infection in pregnancy and newborn. 2020. https://www.gfmer.ch/Guidelines/Maternal neonatal infections/Coronavirus.htm. Accessed 23 Dec 2020.

343. Sharma KA, Kumari R, Kachhawa G, Chhabra A, Agarwal R, Sharma A, et al. Management of the first patient with confirmed COVID-19 in pregnancy in India: from guidelines to frontlines. Int J Gynaecol Obstet. 2020;150(1):116-8.

344. Cimolai N. Complicating infections associated with common endemic human coronaviruses. Health Secur. 2020. https://doi.org/ 10.1089/hs.2020.0067.

Publisher's Note Springer Nature remains neutral with regard to jurisdictional claims in published maps and institutional affiliations. 